\title{
The Paradox of Inequality: Income Inequality and Belief in Meritocracy go Hand in Hand
}

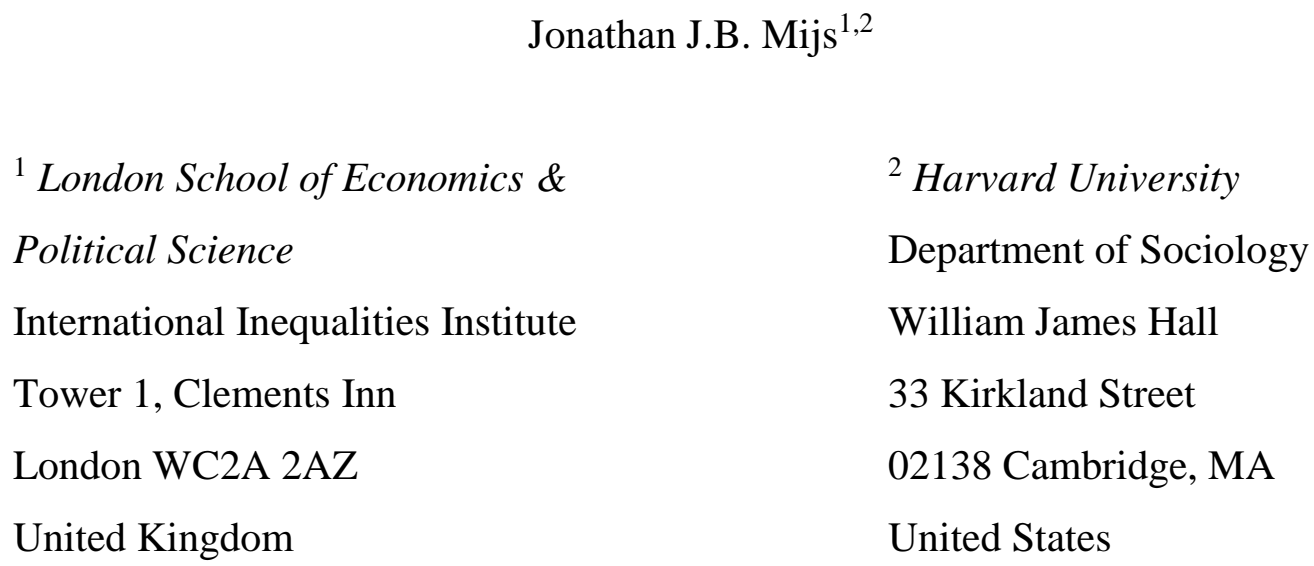

This paper is forthcoming in Socio-Economic Review

\begin{abstract}
Inequality is on the rise: gains have been concentrated with a small elite, while most have seen their fortunes stagnate or fall. Despite what scholars and journalists consider a worrying trend, there is no evidence of growing popular concern about inequality. In fact, research suggests that citizens in unequal societies are less concerned than those in more egalitarian societies. How to make sense of this paradox? I argue that citizens' consent to inequality is explained by their growing conviction that societal success is reflective of a meritocratic process. Drawing on 25years of International Social Survey Programme data, I show that rising inequality is legitimated by the popular belief that the income gap is meritocratically deserved: the more unequal a society, the more likely its citizens are to explain success in meritocratic terms, and the less important they deem non-meritocratic factors such as a person's family wealth and connections.
\end{abstract}

\section{Keywords}

Income; inequality; political attitudes; theory; meritocracy

\section{JEL classification}

Z13 Social and Economic Stratification; D63 Equity, Justice, Inequality, and Other Normative Criteria and Measurement; H Public Economics 


\section{Introduction}

Inequality is on the rise. An impressive body of research describes the dramatic increase in income inequality in the West, in historical and comparative perspective, and offers explanations for this trend (Atkinson et al., 2011; McCall and Percheski, 2010; Morris and Western, 1999; Neckerman and Torche, 2007; Piketty and Saez, 2003). Despite the reality of increasing inequalities, however, the trend has not been accompanied by growing popular concern (Alesina and Glaeser, 2004; Brooks and Manza, 2013; Kenworthy and McCall, 2008; Kuziemko et al., 2015; Larsen, 2016; Lübker, 2007; McCall, 2013). Neither do citizens in more unequal societies express more concern about inequality than those in more egalitarian societies (Bucca, 2016; McCall, 2013; Paskov and Dewilde, 2012; Wietzke, 2016; for a review, see Janmaat, 2013). How to make sense of this paradox?

Scholars have offered various explanations for citizens' lack of concern for the growing gap between the rich and poor. First, people are often misinformed about the actual state of inequality in their society. Specifically, evidence suggests that citizens greatly underestimate just how unequal a society they live in (Cruces et al., 2013; Kenworthy and McCall, 2008; McCall, 2013; Norton and Ariely, 2011; Osberg and Smeeding, 2006; Gimpelson and Treisman, 2018). In other words, citizens may be unconcerned simply because they are unaware of the extent of inequality in their country. A second line of scholarship suggests that living in an unequal society may actually make people more tolerant of inequality, as they get used to it and develop successful coping mechanisms (Bénabou and Tirole, 2006; Jost et al., 2004; Trump, 2017). In this article I draw on these insights to develop an alternative explanation for people's growing tolerance of inequality and their resistance to redistributing income and wealth: I argue that people increasingly believe that inequality is the outcome of a fair, meritocratic, process where societal success simply reflects talent, ambition and hard work.

Figure 1 shows the trend in meritocratic beliefs in different countries in the 1987-2012 period for which we have comparative attitudinal data (see also Mijs, 2018a). Indicated, for each country and time point, is the average score that citizens attributed to hard work in determining who gets ahead in society. A first thing to note is how strongly citizens, across the board, think success depends on hard work. With the exception of communist pre-1989 Poland, a majority in each country and time period believes theirs is a meritocracy society. A second thing to note is that the percentage of people who does, has gone up in almost every country since the late 1980s. 
The West is marked by a striking convergence in citizens' views of success: in the most recent surveys, at least two-thirds of citizens in all countries - and as much as 95 percent of Americans-attribute success to meritocratic factors.

Figure 1. Belief in meritocracy across countries over time.
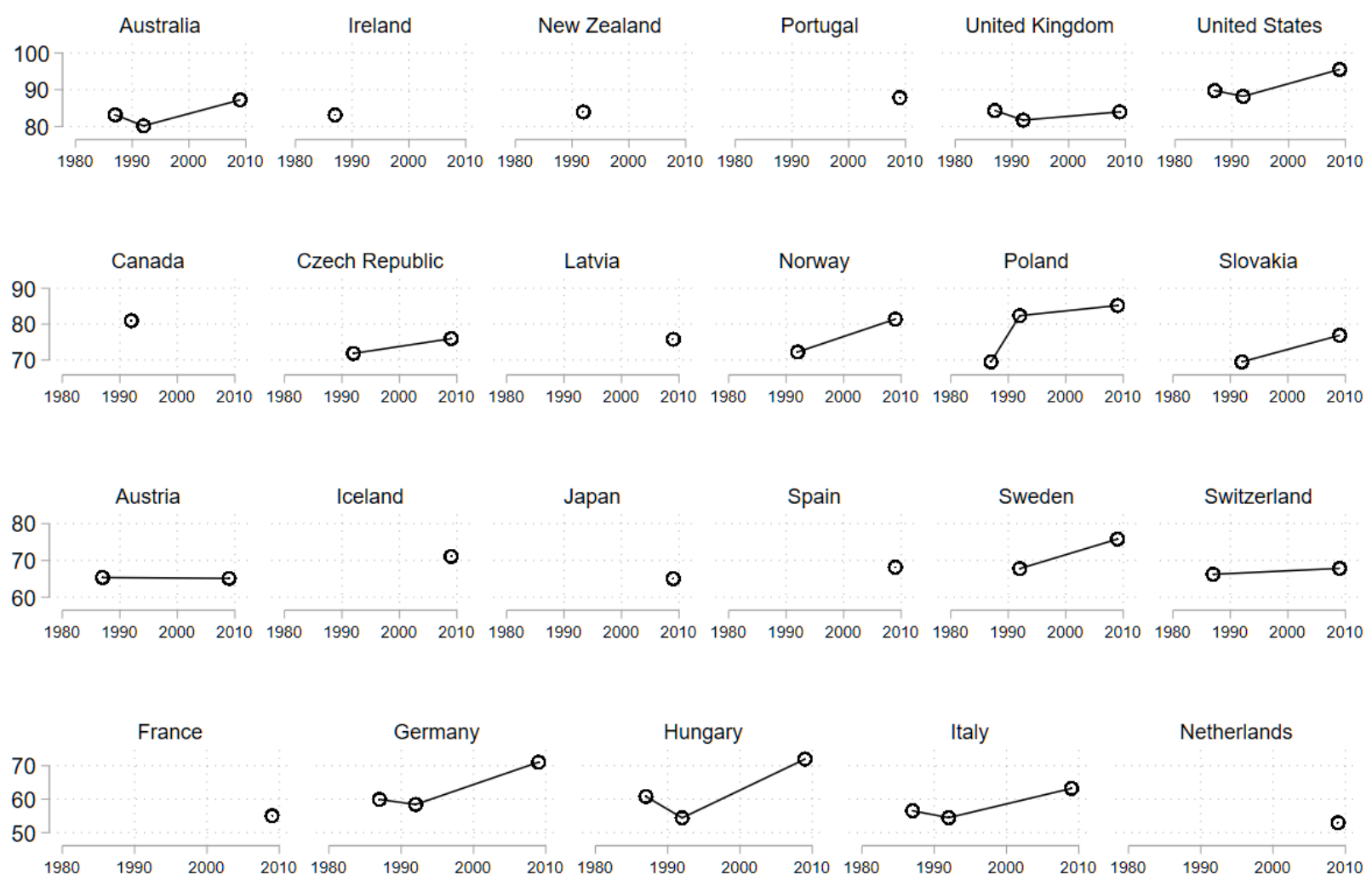

Note: Indicated on the vertical axis is the approximate percentage of citizens, for each country and period, who believes that who gets ahead in society is decided by hard work. Source: Author's calculations from ISSP (2014).

In what follows I explore the relationship between country-level income inequality and citizens' concerns and beliefs about inequality, drawing on pooled data from the International Social Survey Programme, covering 49,383 citizens in 23 countries, over a 25-year period (from 1987 to 2012). In the first step of the analysis, I draw on between-country differences and changes within countries over time to describe how citizens in more unequal societies are more likely to explain success in terms of meritocratic factors and less likely to believe in structural inequality. This relationship is driven mainly by between-country differences, but I also find 
evidence that long-term changes in inequality are accompanied by a stronger belief in meritocracy, while belief in structural inequality remains stable. I confirm the impact of overtime changes in inequality by means of a cohort analysis. Comparing present-day inequality with the level of inequality when a person reached adulthood, I find that citizens who grew up with rising levels of inequality believe more strongly in meritocracy.

In the second step of the analysis, I show that there is no statistical relationship between country-level income inequality and citizens' concerns about inequality. What explains people's concerns are their beliefs about the causes of inequality. I show that citizen's (individual-level) beliefs and popular (country-level) beliefs about inequality explain a large part of their concerns: people who believe inequality reflects hard work are much less concerned about inequality than citizens who see inequality as driven by structural forces such as a person's family wealth and connections.

In sum, income inequality is accompanied by popular beliefs that dampen citizens' concerns by legitimating the growing income gap as meritocratically deserved. I conclude by discussing implications for theory and research.

\section{Theoretical background}

Research documents a trend of growing inequality across the West: over the last three decades, income gains have been concentrated among a small group of citizens, while many have seen their economic position stagnate or fall (Atkinson et al., 2011; McCall and Percheski, 2010; Morris and Western, 1999; Neckerman and Torche, 2007; OECD, 2015). ${ }^{1}$ Today the top 10 percent of households take home 25 percent of all earnings and own more than half of all wealth (OECD, 2015, pp. 34-35). Despite what scholars, journalists and some politicians consider to be a worrying trend, there is no evidence that people have grown increasingly concerned about inequality (Alesina and Glaeser, 2004; Kenworthy and McCall, 2008; Kuziemko et al., 2015; Lübker, 2007; McCall, 2013). The US is the embodiment of this phenomenon: while it is one of

\footnotetext{
${ }^{1}$ The focus here and throughout this paper is on developed countries in the West as defined by membership in the Organisation for Economic Co-operation and Development (OECD). A full list of countries that make up the sample of the empirical analyses presented here is given in Table 1.
} 
the most unequal and least socially mobile society in the West (Breen and Jonsson, 2005; Corak, 2004; Smeeding, 2005; Alesina et al., 2018), its citizens are the most resistant to redistributing income and wealth (Brooks and Manza, 2013; Hochschild, 1996). Scholars suggest that citizens' consent to rising levels of inequality could have its source in cognition, morality or experience. ${ }^{2}$

\subsection{Underestimating inequality: the role of cognition}

On a cognitive level, it may be that people are not well-informed about the trend characterizing their changing societies; they do not know the full extent of it. There is considerable evidence to suggest that people indeed underestimate the degree of inequality in their society-something that is true for Americans as well as citizens of European and Latin American societies (Bucca, 2016; Cruces et al., 2013; Norton and Ariely, 2011; Osberg and Smeeding, 2006). News media may play a part here: McCall (2013) shows that print media in the United States devoted considerable attention to inequality and related themes such as poverty and job insecurity, but that the trend in reporting between 1980 and 2010 did not in any way correspond to actual trends in inequality; if anything, reporting declined since the 1980s, while inequality went up.

The importance of information is underlined by survey experiments indicating that presenting people with facts about the actual state of inequality generally leads them to update their beliefs, although exactly how they do is contested. Nair (2018) finds, in a representative US survey, that correcting people's perception of their rank in the global income distribution, makes them more willing to support foreign aid and donate to charities. Kuziemko et al. (2015) find that

\footnotetext{
2 The question of citizens' concerns about or consent to inequality is related, but both conceptually and empirically distinct from citizens' preferences regarding income redistribution and how inequality ought to be addressed by government, which have been subject to rigorous research (Schmidt-Catran, 2016; Jæger, 2013; Dallinger, 2010). These matters are likely to depend to a greater extent on citizens' political values, trust in government, and other policy preferences, which may mediate the relationship between experiences of inequality, perceptions thereof, and citizens' concerns (cf. Alesina et al., 2018; McCarty and Pontusson, 2011). This means that this study is in conversation with research on citizens' preferences regarding income and wealth redistribution, but my analyses are of citizens' beliefs and perceptions rather than political attitudes, and should not be taken as directly comparable.
} 
providing American citizens with information about real levels of inequality in their society increases their concerns about inequality, but leaves their policy preferences largely unaffected. Alesina, Stantcheva and Teso (2017) replicate the first finding for representative samples of US, British, French, Italian and Swedish citizens. In line with the second finding, Kuklinksi et al. (2000) find that correcting misperceptions about the number of people on welfare and the size of government spending does not change people's preferences. In contrast, Cruces, Perez-Truglia and Tetaz (2013) find that poor people underestimate how much other people make, and learning about their place in the income distribution increases their support for income redistribution. Last, Trump (2017) finds that experiences of inequality may change people's beliefs about the legitimacy of inequality, but in a counterintuitive direction. She designed an experiment where Swedish and American participants are asked to estimate income inequality. Participants in the treatment group are informed about actual income inequality in their society, whereas participants in the control group are not. As a result of the treatment, participants reported a preference for a higher ratio of high-to-low income inequality, by as much as 50 percent. In other words, they upwardly adjusted their tolerance of inequality.

Taken together, whereas these studies suggest that people's beliefs about inequality are based on information, they also indicate that people may respond differently to (new) information about inequality. Consequently, it is unclear how to explain people's consent to inequality through a purely cognitive process.

\subsection{Meritocracy legitimates inequality: the role of morality}

Trump's finding suggests that part of the explanation for citizens' consent to inequality may be that people adjust their ideals in accordance with their perceptions of reality. In fact, research describes how people in more unequal societies grow more tolerant of inequality (Gijsberts, 2002; Schröder, 2017), echoing Marx's claim that the ideological superstructure will follow society's material base. These findings fit with a long line of social psychological research on the legitimation of inequality. The 'belief in a just world' perspective posits a universal tendency to believe that inequalities reflect a meritocratic process, for this allows people to maintain their belief that they live in a fair world rather than having to address inequities (Bénabou and Tirole, 2006; Jost et al., 2004; Lerner, 1980).

In addition to this general psychological tendency, sociologists have described how 
powerful societal groups in particular may have an interest in maintaining their advantages through self-justification (Kluegel and Smith, 1986) or a more dynamic cultural process of boundary making, whereby people in positions of advantage develop beliefs that legitimate closure between them and those below (Lamont, 1992; Lamont et al., 2014). We can think of the American Dream as such a cultural narrative, or repertoire, that elites draw from and reproduce in order to justify their privileges - a cultural solution or coping mechanism for the exceptionally high levels of inequality characterizing the US (Hochschild, 1996; Kelly and Enns, 2010). Neoliberal policies, rolled out throughout the West since the 1980s, have arguably reinforced the notion that success and setbacks in the free market are reflective of individuals' talents, efforts or lack thereof (Hall and Lamont, 2013; Mijs et al., 2016; Somers and Block, 2005). Research indeed suggests that the public increasingly blames the poor for their misfortune and praises the successes of the 'meritocratic' rich (Hills, 2002; MacLeod et al., 1999; Weaver et al., 1995). ${ }^{3}$

Rather than think of the role of cognition and morality (meritocracy) as competing explanations for the lack of popular concern about inequality, the two may in fact be connected. To see how, consider the role of people's own experiences. Despite all the news on inequality, for many people the world as presented in the media, or depicted by politicians, may not correspond to their lived experience (Irwin, 2018; Gimpelson and Treisman, 2018; Edmiston, 2018). Similarly, the meritocratic narrative, while dominant in most Western societies, may ring more true to some than to others. New research suggests that what grounds people's beliefs about inequality is their exposure to and interactions with other people across economic fault lines.

\subsection{Unequal societies and meritocracy beliefs: the role of experiences}

Studies describe how people living among others of the same income level tend to hold meritocratic beliefs, while those living in more economically heterogeneous areas are more likely to think that success is determined by forces outside their control (Merolla et al., 2011; Newman et al., 2015; Wu and Chou, 2017). The latter can see what the former cannot: how life outcomes are shaped by money and resources.

Edmiston (2018, p. 11) reports how in the absence of contact, his affluent interviewees displayed a 'poor sociological imagination,' whereas “[those] who had sustained interaction

\footnotetext{
${ }^{3}$ But see Svalffors (2011) for the contradicting case of Sweden.
} 
with, or experience of, structural constraints were much more likely to recognize the factors that might mitigate an individual's responsibility for their situation or actions." This finding may not be limited to people living in affluence. Research suggests that poor people tend to underestimate the extent of their poverty (Cruces et al., 2013) and sometimes blame themselves for their circumstances (Newman, 1999; McCoy and Major, 2007). Shedd (2015) argues that such beliefs are situated in people's social environments. In her study of Chicago public school students, she finds that "[their] perceptions of the world are indelibly shaped by their place in that world. (...) Youth of color attending segregated schools experience structural discrimination on a daily basis, but they lack the opportunity to make between-race comparisons on a daily basis. Students who cross boundaries, in other words, are more likely to see discrimination than those who do not make these journeys" (Shedd, 2015, p. 58).

These studies continue a line of research originating in the 1950s and 1960s, which describes how people's understanding of society draws on social comparison processes that are both limited and biased by their social context; people's perceptions and beliefs are "bounded by the private orbits in which they live" (Mills, 1959, p. 3). When making comparisons, people draw on a restrictive range of reference groups, namely their co-workers, family and friends who tend to be socio-economically similar to them (Runciman, 1966; Lockwood, 1966; Irwin, 2018; Minkoff and Lyons, 2018; Dawtry et al., 2015). As Irwin (2018, p. 204) puts it, "people read the world from their own situated position and extrapolate from their own experience." As a consequence, people underestimate social inequality (Mijs, 2018b).

Growing levels of income inequality mean that experiences and interactions with people across income, wealth and racial fault lines are becoming more seldom. Research suggests that income inequality creates greater spatial and social distance between the wealthy and the poor, as they live their lives in different institutions: children grow up in poor or wealthy neighborhoods, attend different (public or private) schools, find friends and romantic partners in their own circles, and come to work in increasingly polarized labor markets (Kalleberg, 2009; Massey and Tannen, 2016; Musterd, 2005; Neckerman and Torche, 2007; Owens, 2016; Reardon and Bischoff, 2011; Tammaru et al., 2016). Consequently, I argue, people on either side of the income divide are unable to see the breadth of the gap that separates their lives from those of others: as the gap grows larger, other people's lives fade out of view. Hence, large inequality paradoxically leads to insulate people from seeing the full extent of it. People underestimate the 
structural forces that make for inequality because they are increasingly unable to see it from their (isolated) position at the bottom or top of their (segregated) society. Without direct experiences, news reporting and statistics about (growing) inequality are not likely to change people's perspectives, nor lead them to develop empathy for the plight of unseen others living across the income divide (Roth and Wohlfart, 2017; Newman, 2014; Tropp and Pettigrew, 2005; Edmiston, 2018).

In sum, I hypothesize that citizens' consent to inequality can be explained by their belief that inequalities reflect the legitimate accomplishments of hard work rather than the operation of ('unfair') structural forces beyond their control. Moreover, I posit that inequality creates the social conditions for its legitimation. The statistic of income inequality becomes economic reality when it affects affluent and poor people's wages and employment. It becomes social reality when it impacts the social and spatial environment in which the rich and poor lead their lives. Unequal societies are marked by greater social distance, such that the rich and poor develop an understanding of society and their own place in it from a position of socio-economic insulation. As a result, people in more unequal societies underestimate the extent of inequality and the role of structural advantages or barriers that help or hurt them.

The following hypotheses follow from the preceding discussion.

Hypothesis 1: With greater income inequality, citizens are more likely to understand inequality in meritocratic terms (H1a), and less likely to understand inequality in structural terms (H1b).

Hypothesis 2: Belief in meritocracy leads citizens to be consenting of income inequality (H2a), and belief in the structural causes of inequality leads citizens to be concerned about inequality $(\mathrm{H} 2 \mathrm{~b})$.

In what follows, I put these hypotheses to the test. The next section describes the data and methods, before discussing my findings.

\section{Methodology}

\subsection{Data}

I draw on data from the International Social Survey Programme (ISSP), which is a cross-national survey started in the 1980s by a small group of Western nations (Australia, Germany, Great Britain, and the United States) and has since grown to span more than two decades and cover 
dozens of countries. My analyses build on the cumulative Social Inequality module (ISSP Research Group, 2014), covering three time periods: the first wave, 1987-88, the repeated survey in 1991-93, and the most recent data collected in 2008-2012. Data for each country-period are based on a representative survey of the adult population. ${ }^{4}$ Since my focus in this article is on Western countries undergoing comparable trends, I exclude non-European non-Western nations from the sample. Combining data for the three waves and accounting for missing data, I obtain a final sample of 49,383 in 23 countries and 43 country-periods. The country panel is unbalanced; some countries participated in all three waves, whereas other countries participated only once or twice. The ISSP surveys are fielded in each country by local research centers. Participation in each wave depends on organizational, logistical, and financial factors (for details, see ISSP Research Group, 2014). See Table 1 for the full list of countries and years, and for country-level averages of key variables discussed in the next section.

Table 1. Country-period descriptives $(\mathrm{N}=43)$

$\begin{array}{lrrrrrrr}\text { Country } & \text { Year } & \text { Code } & \text { Gini } & \text { GDP } & \text { Concern } & \text { Merit } & \text { Structure } \\ \text { Australia } & 1987 & \text { AU87 } & 40.6 & 27,817 & 63.0 & 83.1 & 38.0 \\ \text { Australia } & 1992 & \text { AU92 } & 42.0 & 29,048 & 64.8 & 80.2 & 48.4 \\ \text { Australia } & 2009 & \text { AU09 } & 31.4 & 41,841 & 72.8 & 87.2 & 44.9 \\ \text { Austria } & 1987 & \text { AT87 } & 23.0 & 27,471 & 82.9 & 65.4 & 72.6 \\ \text { Austria } & 2009 & \text { AT09 } & 27.8 & 41,222 & 82.8 & 65.1 & 62.8 \\ \text { Canada } & 1992 & \text { CA92 } & 35.6 & 29,773 & 70.0 & 81.0 & 37.7 \\ \text { Czech Republic } & 1992 & \text { CZ92 } & 21.0 & 17,181 & 71.8 & 71.9 & 52.2 \\ \text { Czech Republic } & 2009 & \text { CZ09 } & 25.3 & 26,885 & 81.8 & 76.0 & 62.6 \\ \text { France } & 2009 & \text { FR09 } & 32.9 & 35,536 & 88.8 & 55.0 & 24.9 \\ \text { Germany } & 1987 & \text { DE87 } & 35.2 & 27,383 & 71.7 & 59.9 & 64.5 \\ \text { Germany } & 1992 & \text { DE92 } & 30.8 & 32,120 & 80.7 & 58.4 & 59.0 \\ \text { Germany } & 2009 & \text { DE09 } & 30.6 & 38,331 & 84.2 & 71.1 & 69.6 \\ \text { Hungary } & 1987 & \text { HU87 } & 21.0 & 14,564 & 75.8 & 60.8 & 54.7 \\ \text { Hungary } & 1992 & \text { HU92 } & 27.8 & 14,148 & 79.9 & 54.4 & 52.0 \\ \text { Hungary } & 2009 & \text { HU09 } & 27.4 & 21,274 & 93.6 & 72.0 & 65.6 \\ \text { Iceland } & 2009 & \text { IS09 } & 28.5 & 39,678 & 83.3 & 71.1 & 75.5 \\ \text { Ireland } & 1987 & \text { IR87 } & 35.2 & 17,327 & 76.0 & 83.1 & 55.2\end{array}$

\footnotetext{
${ }^{4}$ Sampling procedures vary from country to country. For details, see ISSP Research Group (2014).
} 


$\begin{array}{lrrrrrrr}\text { Italy } & 1987 & \text { IT87 } & 31.8 & 27,522 & 81.0 & 56.5 & 82.5 \\ \text { Italy } & 1992 & \text { IT92 } & 30.5 & 30,851 & 84.7 & 54.5 & 78.1 \\ \text { Italy } & 2009 & \text { IT09 } & 32.7 & 34,320 & 89.4 & 63.2 & 64.2 \\ \text { Japan } & 2009 & \text { JP09 } & 32.1 & 33,598 & 77.9 & 65.1 & 20.1 \\ \text { Latvia } & 2009 & \text { LV09 } & 36.2 & 17,906 & 87.9 & 75.8 & 65.4 \\ \text { Netherlands } & 2009 & \text { NL09 } & 28.8 & 44,207 & 68.5 & 53.0 & 50.9 \\ \text { New Zealand } & 1992 & \text { NZ92 } & 38.2 & 21,578 & 72.2 & 84.0 & 34.6 \\ \text { Norway } & 1992 & \text { NO92 } & 25.1 & 42,149 & 69.3 & 72.3 & 36.1 \\ \text { Norway } & 2009 & \text { NO09 } & 26.3 & 58,368 & 62.9 & 81.4 & 38.3 \\ \text { Poland } & 1987 & \text { PL87 } & 24.3 & 9,976 & 78.9 & 37.6 & 63.9 \\ \text { Poland } & 1992 & \text { PL92 } & 25.0 & 9,474 & 79.9 & 82.4 & 74.9 \\ \text { Poland } & 2009 & \text { PL09 } & 34.1 & 20,296 & 84.0 & 85.2 & 79.2 \\ \text { Portugal } & 2009 & \text { PT09 } & 36.2 & 26,864 & 88.8 & 87.8 & 56.5 \\ \text { Slovakia } & 1992 & \text { SK92 } & 20.2 & 11,560 & 82.3 & 68.2 & 64.9 \\ \text { Slovakia } & 2009 & \text { SK09 } & 26.0 & 23,694 & 88.0 & 76.9 & 74.4 \\ \text { Spain } & 2009 & \text { ES09 } & 30.7 & 32,124 & 79.7 & 68.2 & 62.5 \\ \text { Sweden } & 1992 & \text { SE92 } & 24.9 & 28,959 & 64.7 & 67.8 & 43.5 \\ \text { Sweden } & 2009 & \text { SE09 } & 25.5 & 39,650 & 73.0 & 75.8 & 43.3 \\ \text { Switzerland } & 1987 & \text { CH87 } & 35.7 & 41,349 & 68.0 & 66.2 & 46.0 \\ \text { Switzerland } & 2009 & \text { CH09 } & 32.3 & 51,750 & 79.8 & 67.9 & 54.6 \\ \text { United Kingdom } & 1987 & \text { UK87 } & 33.2 & 24,373 & 72.4 & 84.3 & 43.9 \\ \text { United Kingdom } & 1992 & \text { UK92 } & 36.8 & 26,077 & 77.0 & 81.7 & 36.3 \\ \text { United Kingdom } & 2009 & \text { UK09 } & 37.5 & 35,354 & 75.2 & 84.0 & 34.8 \\ \text { United States } & 1987 & \text { US87 } & 42.6 & 33,898 & 73.1 & 89.8 & 49.3 \\ \text { United States } & 1992 & \text { US92 } & 43.3 & 36,508 & 73.1 & 88.2 & 45.9 \\ \text { United States } & 2009 & \text { US09 } & 46.8 & 47,503 & 69.1 & 95.5 & 54.5\end{array}$

Note. Gini is the Gini coefficient of income inequality for that country and year, GDP is the Gross Domestic Product in US Dollars. The next three columns give the country-level average, in that survey year, of citizens' concerns about inequality (Concern), belief in meritocracy (Merit) and their belief in structural inequality (Structure). Source: Milanovic (2013), OECD (2017) and author's sample of International Social Survey Programme 1987-2009.

\subsection{Dependent variables}

I measure citizens' concerns about inequality as their response to the following question:

"Income differences in [country] are too high." Responses fall in one of five categories: strongly agree / agree / neither agree nor disagree / disagree / strongly disagree. For ease of interpretation, I follow Larsen's (2016) strategy to reverse-code and multiply the five points to get a scale resembling percentages; ranging from 0 (not concerned at all) to 50 (not concerned nor 
unconcerned) to 100 (very concerned). ${ }^{5}$

In measuring beliefs about inequality I draw on a set of questions inviting survey participants to evaluate the relative importance of several meritocratic and non-meritocratic factors in determining life outcomes (cf. Duru-Bellat and Tenret, 2012; Kluegel and Smith, 1986; Larsen, 2016; McCall, 2013; Reynolds and Xian, 2014). The question reads as follows: "Please tick one box for each of [the following] to show how important you think it is for getting ahead in life..." (1) hard work, (2) having ambition, (3) having a good education, (4) coming from a wealthy family, (5) knowing the right people, (6) a person's race, (7) a person's religion, (8) being born a man or a woman. For each factor, people are asked to indicate, on a five-point scale, whether it is essential / very important / fairly important / not very important / not important at all. As with concerns about inequality, I multiply the five points to get a scale resembling percentages; ranging from 0 (not important at all) to 50 (fairly important) to 100 (essential).

In what follows my focus will be on the first factor-hard work (Bucca, 2016; Kluegel and Smith, 1986; McCall, 2013; Reynolds and Xian, 2014). Hard work is arguably the most meritocratic part of Michael Young's equation, 'Merit = Intelligence + Effort', for the simple fact that intelligence itself is conditioned by a non-meritocratic factor: who your parents happen to be (Mijs, 2016). I prefer to look at the importance people attribute to hard work instead of a person's education or ambitions for the latter are reflective of that person's social background and family resources, as has been well-described by social stratification research (Bozick et al., 2010; Halleröd, 2011). Unless otherwise noted, when I discuss meritocracy beliefs I am referring to citizens' belief in the importance of hard work relative to structural factors.

My measure of belief in structural inequality is based on responses indicating that a person thinks coming from a wealthy family or knowing the right people (factors four and five, respectively) is "very important" or "essential" for getting ahead in life. I look at these two rather than the full set of structural factors for two reasons. First, the cultural meaning of the other structural factors, referring to a person's race, religion, and gender, is likely to vary considerably over time and between societies. As a result, citizens' evaluations of these factors may not be strictly comparable. Second, family wealth and connections are the only factors included in all survey waves, whereas the other categories are missing for some countries and years.

\footnotetext{
${ }^{5}$ This linear transformation does not affect any of the trends or model outcomes I present.
} 


\subsection{Independent variables}

I include two independent variables at the country level, namely the level of income inequality, and the level of economic development. The former is measured by taking the Gini coefficient of income inequality for each country-period (cf. Duru-Bellat and Tenret, 2012; Gugushvili, 2016; Paskov and Dewilde, 2012; Schröder, 2017), drawn from Milanovic' (2013) All the Ginis data set. As a measure of economic development I take GDP per capita (cf. Schröder, 2017; VanHeuvelen, 2017), as provided by the OECD Compendium of Productivity Indicators (OECD, 2017). Descriptive statistics for all country-periods in my sample are provided in Table 1.

I include individual-level measures of people's position in society as proxies for their experiences with inequality. I consider to what extent people's concern and beliefs about inequality co-vary with their age, gender, education, employment status, social class and religion (cf. Bucca, 2016; Hunt, 2002; Kluegel and Smith, 1986; Reynolds and Xian, 2014; Minkoff and Lyons, 2018). For religion, I use dummies indicating Catholicism, Protestantism, Islam, Judaism, and no religion. For employment status I use dummy variables indicating whether a person was full-time employed or not, whether they were a student and whether they had retired at the time of data collection. I look at two measures of a person's social background, reflecting both their objective social position as well as a person's perception of their place in society (Bucca, 2016; Gugushvili, 2016). As a first measure, I take a person's class position in three groups, based on their job and income level (cf. Bucca, 2016; Larsen, 2016): lower or working class / lower middle class or middle class / upper middle class or upper class. As a second measure of a person's social background I take their response to the following question: "In our society there are groups which tend to be towards the top and groups which tend to be towards the bottom. Below is a scale that runs from top to bottom. Where would you put yourself now on this scale?" Responses are on a 1-10 scale, where 1 indicates the "bottom or lowest rung" and 10 indicates the "top or highest rung." I take the first and last three categories as indicating low and high status, respectively, and consider the four categories in-between as mid-level.

Last, I look at a person's social mobility experience, for research suggests that people's concerns and beliefs about inequality may be informed by people's standing in society relative to their parents (Gugushvili, 2016; Larsen, 2016). Specifically, I draw on an indicator of a respondents' job status, as compared to their father's job status when they were a child: "Please 
think about your present job (or your last one if you don't have one now). If you compare this job to the job your father had when you were 14-16 years old, would you say that the level of status of your job is (or was)." Response categories are as follows: much higher / higher / about equal / lower / much lower / never had a job / don't know. I drop the last two and combine the remaining categories into a three-point scale indicating downward social mobility, intergenerational stability, or upward mobility. Descriptive statistics for all variables are provided in Table A1 in the online Appendix.

\subsection{Analytical approach}

To explain variation in citizens' concerns about inequality and their meritocratic and structural beliefs about inequality, I estimate three-level hierarchical linear regression models with randomintercepts for country-periods and countries to account for the nesting of individuals (level 1) in country-periods (level 2) and countries (level 3) (cf. Schmidt-Catran, 2016; and see SchmidtCatran and Fairbrother, 2016). Following Fairbrother (2014), I code my independent variables so as to distinguish between within-country (over-time) changes, on the one side, and betweencountry differences on the other. To do so, I first calculate the mean value of income inequality, Gini $_{M}$, and inequality beliefs, Beliefs ${ }_{M}$, for each country-period. I then calculate between-country inequality as the average level of inequality for each country, across the different time periods; Gini $_{\mathrm{BW}}$ and Beliefs $\mathrm{BW}$, respectively. By subtracting the between-country average from the country-year value, I obtain an estimate of the over-time changes within each country: Gini ${ }_{M}^{-}$ Gini $_{\mathrm{BW}}=$ GiniwI, and Beliefs $\mathrm{M}-$ Beliefs $_{\mathrm{BW}}=$ BeliefswI. To account for general trends over time, I also include period fixed-effects in each model (a dummy for each time period). In the first set of analyses, I estimate models of the form

$$
\text { Belief }_{i t j}=\beta_{0}+\beta_{1} \text { Gini }_{j B W}+\beta_{2} \text { Gini }_{t j W I}+\beta_{3} \text { time_period }_{t}+\beta X_{i t j}+u_{j}+u_{t j}+e_{i t j}
$$

where Belief $f_{i t j}$ indicates the inequality belief held by person $i$ in country-period $t$ in country $j ; \beta_{0}$ is the intercept, $\beta_{1}$ is a coefficient for between-country differences in income inequality, $G i n i_{j B W}$, for country $j ; \beta_{2}$ is the coefficient for within-country changes in income inequality over time, $\operatorname{Gini}_{t j W I}$, for country $j$ in time-period $t ; \beta_{3}$ is a coefficient for time_period $_{t}$ which is a dummy variable indicating the time-period; $\beta$ is a vector of 
coefficients for a vector of individual-level control variables, $X_{i t j}, u_{j}$ indicates a random intercept for the country-level, $u_{t j}$ is a random intercept for the country-period level, and $e_{i t j}$ is the individual-level error term.

In the second set of analyses, I estimate models of the form

$$
\begin{aligned}
\text { Concern }_{i t j}= & \beta_{0}+\beta_{1} \text { Gini }_{j B W}+\beta_{2} \text { Gini }_{t j W I}+\beta_{3} \text { Beliefs }_{j B W}+\beta_{4} \text { Beliefs }_{t j W I} \\
& +\beta_{5} \text { time_period }_{t j}+\beta X_{i t j}+u_{j}+u_{t j}+e_{i t j}
\end{aligned}
$$

where Concern $_{i t j}$ indicate concerns about inequality for person $i$ in country-period $t$ and country $j$. The model is otherwise exactly specified as equation 1, with the exclusion of countrylevel inequality beliefs.

Estimating random-intercept models, instead of country fixed-effects, means I treat my sample as randomly drawn from the larger theoretical population of all Western countries at any point in time, rather than just the set of countries and periods that constitute my empirical sample (Bryan and Jenkins, 2016; Snijders and Bosker, 2012). The number of higher-level units in my sample (43 country-periods) exceeds the minimum number of units (30) required for unbiased estimates of the individual and country-level effects (Bryan and Jenkins, 2016).

\section{Results}

\subsection{Citizens' concerns and beliefs about inequality}

Figure 2 shows the bivariate relationship between country-level income inequality and popular concerns about inequality. The figure describes a negative relationship between income inequality and concerns about inequality at the country level: greater inequality is associated with less, not more, concern about inequality $\left(r=-0.37 ; \mathrm{R}^{2}=0.12\right)$. The pattern is driven almost entirely by two countries; removing Australia and the United States from the set of observations renders the relationship null $\left(r=0.10 ; \mathrm{R}^{2}=0.01\right.$; and see Figure A1 in the Appendix).

In Figure 3, I explore the theorized relationship between income inequality and popular beliefs about inequality. Shown is the country-level relationship between popular inequality beliefs (vertical axis) by the Gini coefficient of income inequality (horizontal axis). Popular belief in meritocracy is depicted as grey diamonds, belief in structural inequality is marked by black circles. Income inequality is positively associated with meritocracy beliefs and negatively 
associated with structuralist beliefs about inequality, meaning that citizens in more unequal societies are more likely than those in more egalitarian countries to believe that societal success is reflective of a meritocratic process. The former relationship is strong $(\mathrm{r}=0.57)$ and explains about 33 percent of the association; the latter relationship is considerably weaker $(r=-0.30)$ and explains about 9 percent of the association.

Figure 2. Country-level income inequality and citizens' concerns about inequality.

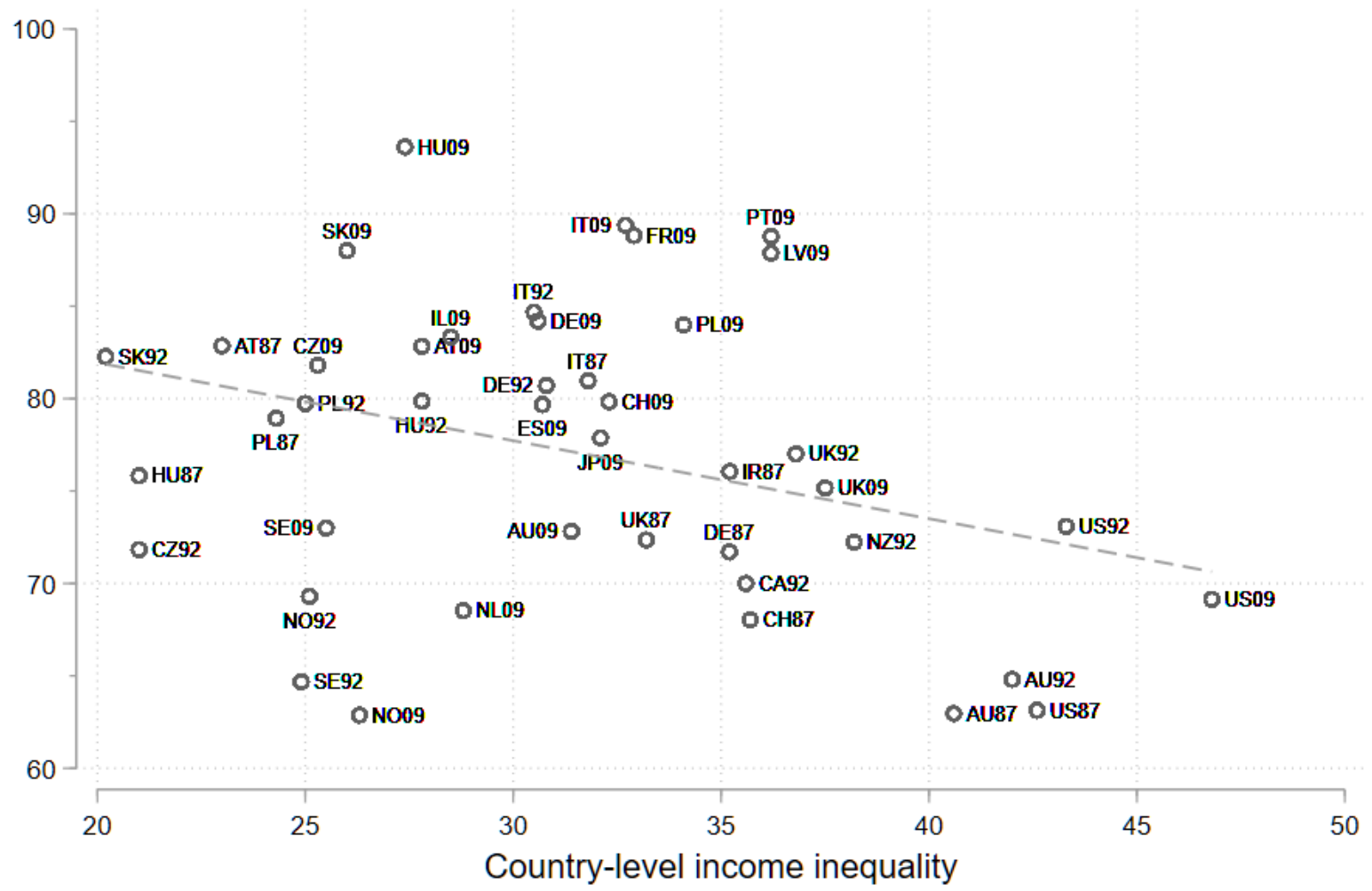

Note: Each circle indicates the average level of concerns about inequality for the country and period, as indicated by the two-character country code and two-number year (see Table 1). Concerns are measured on a scale from 0 (not concerned at all) to 100 (very concerned). Indicated on the horizontal axis is country-level inequality, measured as the Gini coefficient of income inequality ranging from 0 (equality) to 100 (maximum inequality). Source: Author's calculations from ISSP (2014) and Milanovic (2013). 
Figure 3. Country-level income inequality and citizens' inequality beliefs.

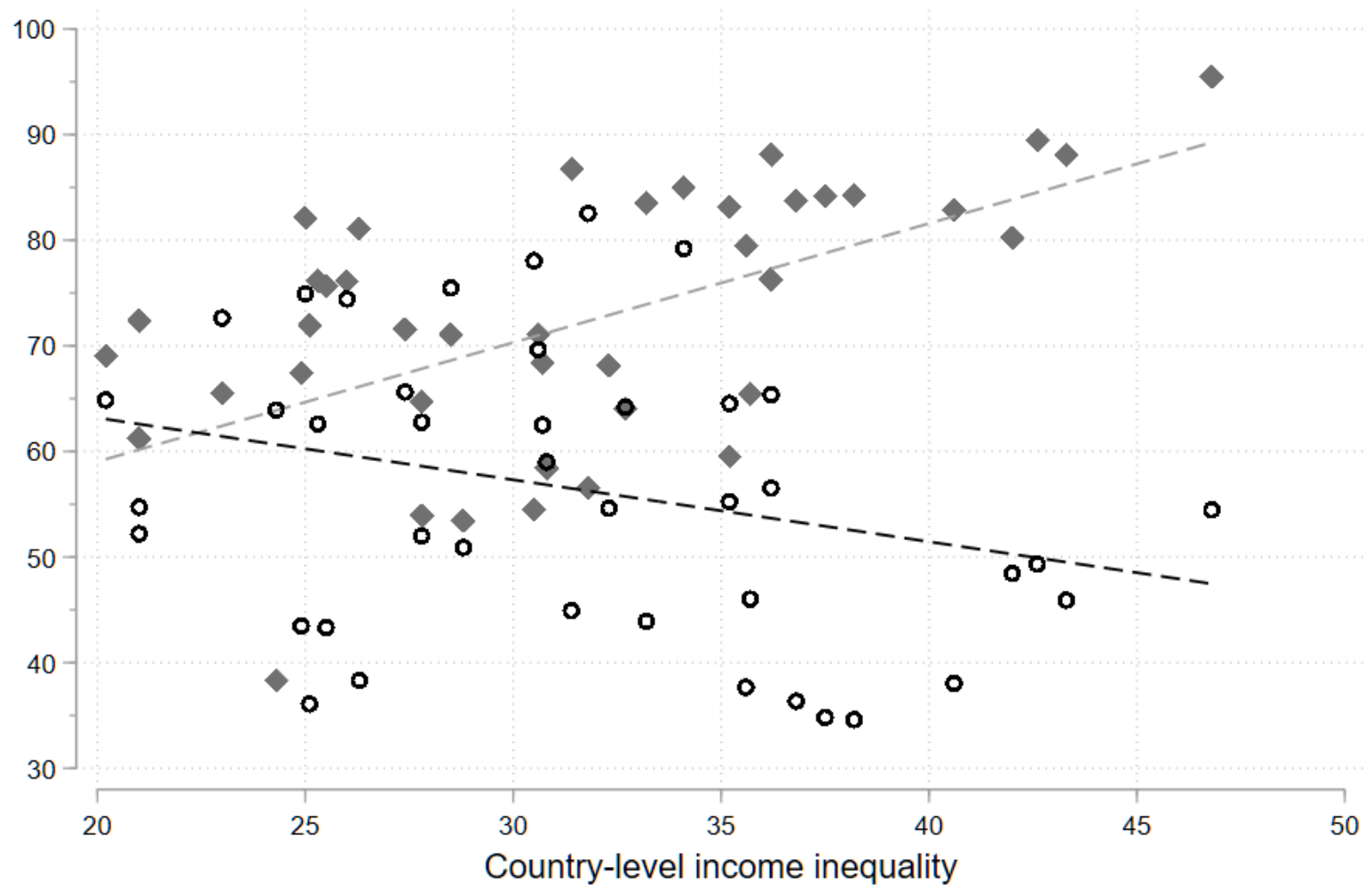

Note: Each grey diamond indicates the average belief in meritocracy for citizens in that country and time-period (vertical axis) by country-level inequality (horizontal axis), measure as the Gini coefficient of income inequality ranging from 0 (equality) to 100 (maximum inequality). A circle indicates the corresponding belief in structural inequality, also indicated on the vertical axis. Source: Author's calculations from ISSP (2014) and Milanovic (2013).

Taking the two figures together, gives a first sketch of the spurious relationship between income inequality and citizens' concerns about inequality, and the importance of beliefs about inequality: if income inequality goes hand in hand with stronger meritocratic beliefs and weaker structuralist beliefs, then that would explain why citizens in unequal countries are not more concerned about inequality. In what follows I put this explanation to the test, turning first to the relationship between country-level income inequality and individual-level beliefs about inequality, before investigating the determinants of citizens' concerns about inequality. 
Table 2. Hierarchical linear regression predicting citizens' inequality beliefs

\begin{tabular}{|c|c|c|c|c|c|c|c|c|c|c|c|c|}
\hline $\begin{array}{l}\text { Variables } \\
\text { Individual-level controls }\end{array}$ & \multicolumn{2}{|c|}{$\begin{array}{l}\text { Meritocracy } \\
\text { Model } 1\end{array}$} & \multicolumn{2}{|c|}{$\begin{array}{l}\text { Meritocracy } \\
\text { Model } 2\end{array}$} & $\begin{array}{l}\text { Meritocra } \\
\text { Model } 3 \\
\text { X }\end{array}$ & & \multicolumn{2}{|c|}{$\begin{array}{l}\text { Structural ineq. } \\
\text { Model } 4\end{array}$} & \multicolumn{2}{|c|}{$\begin{array}{l}\text { Structural ineq. } \\
\text { Model } 5\end{array}$} & \multicolumn{2}{|c|}{$\begin{array}{l}\text { Structural ineq. } \\
\text { Model } 6\end{array}$} \\
\hline Country-level inequality & & & & & & & & & & & & \\
\hline Between-countries & & & $0.58 * * *$ & $(.17)$ & $0.64 * * *$ & $(.18)$ & & & $-0.94+$ & $(.51)$ & -0.75 & $(.51)$ \\
\hline Within-countries & & & -0.14 & $(.12)$ & -0.15 & $(.14)$ & & & 0.01 & $(.45)$ & -0.33 & $(.47)$ \\
\hline Economic development & & & & & & & & & & & & \\
\hline Between-countries & & & -0.11 & $(.16)$ & -0.11 & $(.16)$ & & & 0.54 & $(.53)$ & 0.55 & $(.53)$ \\
\hline Within-countries & & & -0.07 & $(.27)$ & -0.06 & $(.27)$ & & & -0.41 & $(.28)$ & -0.41 & $(.27)$ \\
\hline Social class & & & & & & & & & & & & \\
\hline Working class & & & ref. & & ref. & & & & ref. & & ref. & \\
\hline Lower middle & & & 0.09 & $(.24)$ & $3.79 * *$ & $(1.26)$ & & & $-3.59 * * *$ & $(.55)$ & $5.70 *$ & $(2.86)$ \\
\hline Upper middle & & & $1.13 * *$ & $(.44)$ & 2.04 & $(2.47)$ & & & $-4.80 * * *$ & $(.99)$ & 8.22 & $(5.62)$ \\
\hline Time-period & & & & & & & & & & & & \\
\hline 1991-1993 & & & -1.25 & $(.91)$ & -1.23 & $(.92)$ & & & -5.08 & $(3.31)$ & -4.88 & $(3.32)$ \\
\hline 2008-2012 & & & $3.62+$ & $(1.90)$ & $3.62+$ & $(1.92)$ & & & -3.92 & $(6.36)$ & -3.83 & $(6.36)$ \\
\hline Social class interactions & & & & & & & & & & & & \\
\hline $\begin{array}{l}\text { Lower middle class } \mathrm{X} \text { income } \\
\text { inequality }(\mathrm{b} / \mathrm{w})\end{array}$ & & & & & $-0.11 * *$ & $(.04)$ & & & & & $-0.28 * * *$ & $(.09)$ \\
\hline $\begin{array}{l}\text { Upper middle class } \mathrm{X} \text { income } \\
\text { inequality }(\mathrm{b} / \mathrm{w})\end{array}$ & & & & & -0.03 & $(.08)$ & & & & & $-0.40 *$ & $(.17)$ \\
\hline $\begin{array}{l}\text { Lower middle class } \mathrm{X} \text { income } \\
\text { inequality (w/i) }\end{array}$ & & & & & 0.03 & $(.10)$ & & & & & $0.47 *$ & $(.22)$ \\
\hline $\begin{array}{l}\text { Upper middle class } \mathrm{X} \text { income } \\
\text { inequality (w/i) }\end{array}$ & & & & & -0.17 & $(.17)$ & & & & & $0.67+$ & $(.40)$ \\
\hline Constant & $74.3 * * *$ & $(1.15)$ & $60.4 * * *$ & $(6.53)$ & $58.3 * * *$ & $(6.57)$ & $54.5 * * *$ & $(3.17)$ & $117.4 * * *$ & $(19.0)$ & $111.2 * * *$ & $(19.0)$ \\
\hline Var (country) & $4.83 * * *$ & $(.91)$ & $4.17 * * *$ & $(.71)$ & $4.17 * * *$ & $(.71)$ & $13.9 * * *$ & $(2.4)$ & $11.7 * * *$ & $(2.1)$ & $11.7 * * *$ & $(2.1)$ \\
\hline Var (country-period) & $2.76 * * *$ & $(.51)$ & $1.41 * * *$ & $(.31)$ & $1.43 * * *$ & $(.31)$ & $6.08 * * *$ & (1.1) & $5.58 * * *$ & $(1.1)$ & $5.60 * * *$ & $(1.1)$ \\
\hline Var (individual) & $20.8 * * *$ & $(.07)$ & $20.6 * * *$ & $(.07)$ & $20.6 * * *$ & $(.07)$ & $47.6 * * *$ & $(.16)$ & $47.2 * * *$ & $(.16)$ & $47.3 * * *$ & $(.16)$ \\
\hline
\end{tabular}

Note. The first three models predict citizens' belief in meritocracy; the last three models predict belief in structural inequality. w/i refers to withincountry; b/w refers to between-country. $\mathrm{N}=49,383$ individuals in 43 country-periods and 23 countries. $* * *=p<.001 ; * *=p<.01 ; *=p<.05 ;+$ $=\mathrm{p}<.10$ (two-sided). Source: Author's sample of International Social Survey Programme 1987-2009. 


\subsection{Explaining citizens' beliefs about inequality}

Table 2 presents the results of hierarchical linear models estimating individual citizens' beliefs about inequality, as explained by the level of inequality in their country. I decompose the country-level inequality into that part of income inequality that is unique to the country (an overtime average) and the part that changed over time. The former allows me to establish the relationship between citizens' beliefs about inequality and between-country differences in income inequality. The latter is a measure of the within-country changes in income inequality over time. Substantively, it shows whether citizens of those countries that experienced the fastest growth of income inequality, between the first two waves (1987-1992) or between the second and third (1992-2012), also show the largest increase in meritocratic beliefs and the steepest decline in their belief in structural inequality.

Models 1-3 predict citizens' belief in meritocracy, Models 4-6 predict citizens' belief in structural inequality. Null models 1 and 4 estimate that about 73 and 70 percent of variance in people's belief in meritocracy and structural inequality, respectively, is due to individual-level factors. About 10 and 9 percent can be attributed to differences between country-periods, and 17 and 21 percent of variance in the respective beliefs is due to country-level factors.

Model 2 includes country-level measures of income inequality and economic development, and individual-level controls. Both country-level measures are broken down by between-country differences and within-country (over-time) changes. In line with my theoretical expectations, I find a positive and statistically significant $(0.58 ; \mathrm{p}<.001)$ relationship between income inequality and citizens' meritocratic beliefs (cf. Hypothesis 1a): all else equal, citizens living in a country with a high level of income inequality like the US (Gini score of 44) have a stronger belief in meritocracy by about 12 points compared to those living in a more egalitarian society like Austria (Gini score of 23). This relationship is driven by between-country differences; contrary to expectations, changes in societal income inequality between survey waves do not explain differences in citizens' inequality beliefs. Results further suggest that a person's subjective social status, social class, and level of education are positively associated with believing in meritocracy $(\mathrm{p}<.001)$, as is upward social mobility, as compared to downward mobility. Having a full-time job is similarly associated with belief in meritocracy $(0.79, \mathrm{p}<.01)$, whereas unemployment is negatively associated with such beliefs, albeit not significantly (at $\mathrm{p}<$ .10). Non-religious people are less likely to believe in meritocracy than most religious people (- 
$0.81, \mathrm{p}<.10)$, as are Jewish people $(-3.09 ; \mathrm{p}<.05)$, whereas Muslims $(2.76 ; \mathrm{p}<.10)$ and Protestants $(1.37 ; \mathrm{p}<.01)$ believe more strongly in meritocracy. Older people are less likely to believe in meritocracy than younger people $(-0.11, \mathrm{p}<.01)$, but the effect is curvilinear, diminishing with the years. See Table A2 in the Appendix for full results. The model leads to a reduction in variance of about 1 percent at the individual level, 49 percent at the country-period level and 14 percent at the country level.

Model 3 includes an interaction-effect between social class and income inequality to assess whether the relationship between income inequality and meritocratic beliefs differs by social class position. I find a negative interaction effect for (lower) middle class people, as compared to working class citizens, indicating that the association between inequality and beliefs is stronger for the latter than the former. Including the interaction-term does not lead to a further reduction in the variance components.

Model 5 describes a negative relationship between country-level income inequality and citizens' belief in structural inequality: citizens in more unequal societies are less likely to understand inequality in structural terms (cf. Hypothesis 1b). I do not find a statistically significant relationship between structuralist beliefs and within-country changes in inequality. At the individual-level, I find that citizens with higher subjective social status, education, and social class are less likely to understand inequality in structural terms, as are people who have experienced upward social mobility. The same is true for retired people, actively employed people, and Protestants. Conversely, unemployed citizens and women are more likely to believe in structural inequality. The model reduces the variance components at the individual level by about 1 percent, by 8 percent at the country-period level, and by 16 percent at the country-level.

Model 6 describes two interaction-effects: I find that the negative relationship between country-level inequality and structuralist inequality beliefs is stronger for lower and upper middle class people, compared to working class citizens; and I find a negative relationship between over-time changes in inequality and structuralist beliefs for working class citizens, but a small positive relationship for lower and upper middle class people. The latter interaction, while statistically significant (at the $\mathrm{p}<.10$ and $\mathrm{p}<.05$ level) is substantively weak. 
Figure 4. Predictive margins of citizens' inequality beliefs by social class and country-level income inequality.

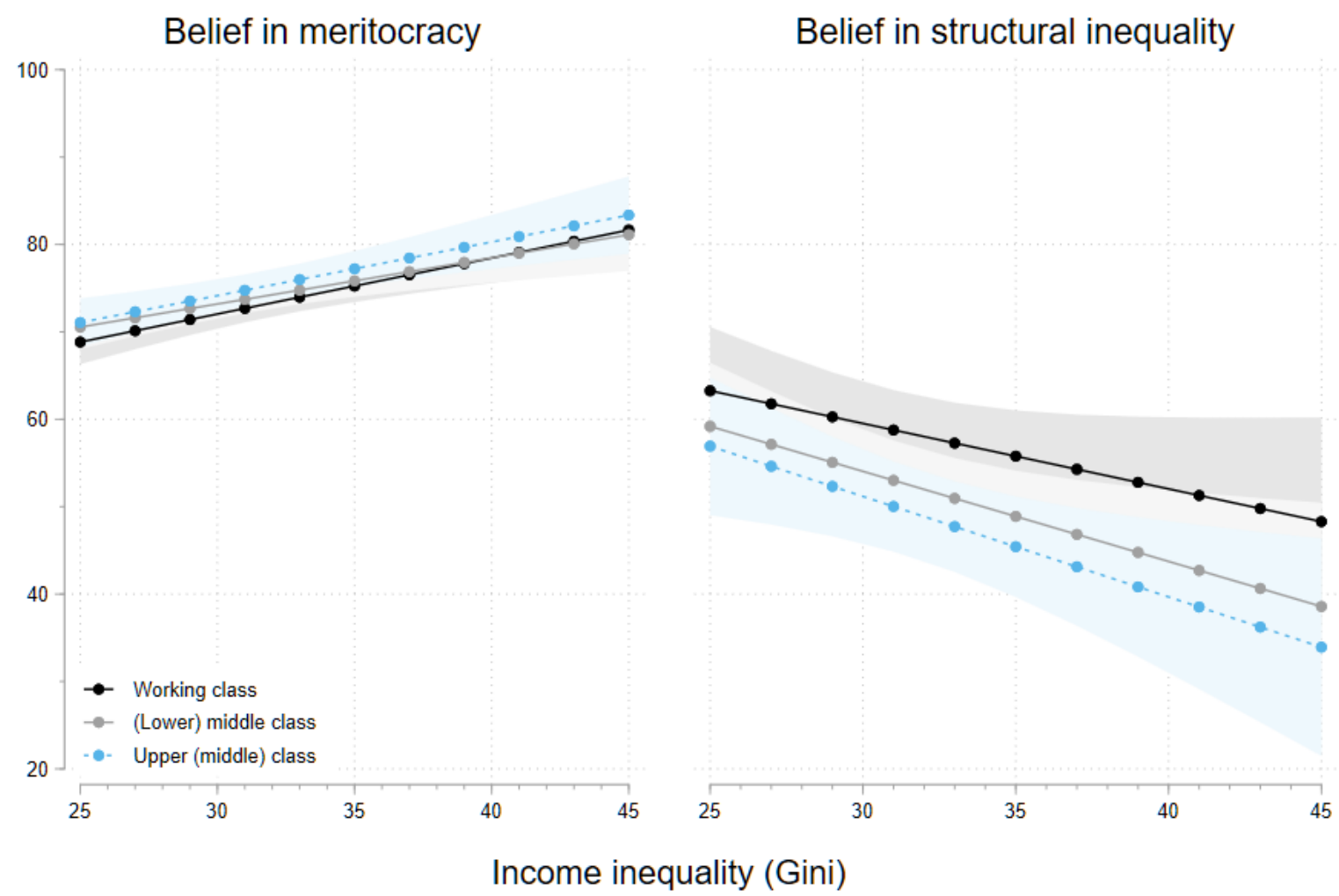

Note: Displayed are citizens' belief in meritocracy (left) and structural inequality (right), on the vertical axis, predicted by their social class and by the extent of country-level income inequality (horizontal axis). Predictive margins are based on regression estimates reported in Table 2, Models 3 and 6. Source: Author's calculations from ISSP (2014).

To visualize the interaction between country-level inequality and citizens' inequality beliefs by social class, I calculate and plot predictive margins in Figure 4. The upward lines in the left-side graph indicate the positive relationship between country-level income inequality and citizens' belief in meritocracy. The difference in citizens' beliefs, comparing the most egalitarian to the most unequal countries, is about 10 points, or half a standard-deviation. Whereas there is significant variation in beliefs by citizens' social class, the substantive differences are minimal; citizens across social classes hold strong beliefs in meritocracy. There are larger differences by social class in citizens' structuralist beliefs (right-side graph). Working class citizens are much more likely to believe in structural inequality, and their beliefs are less affected by country-level 
income inequality. Lower and upper middle class citizens are much less likely to believe in structural inequality when they live in more unequal societies, by as much as 20 points, although it should be noted that the confidence intervals are very large such that we should be careful not to overstate the size of the effect.

In sum, citizens in more unequal societies understand income inequality in meritocratic rather than structural terms, while people in more egalitarian countries see structural inequality. Statistically, these associations are driven almost entirely by relatively stable between-country differences rather than over-time changes in income inequality. In other words, knowing the level of income inequality in a country, relative to other countries, gives us purchase on their beliefs about inequality. Knowing how income inequality in a given society has changed between survey waves however does not help explain citizens' beliefs.

A difference between the estimates of between and within-country inequality indicates that the estimates are biased. The limited amount of within-country variation in income inequality means I lack the statistical power to estimate their statistical relationship more precisely. Consequently, I urge caution in interpreting the coefficients as describing a causal effect of between-country income inequality on inequality beliefs. Rather, the statistical association indicates a relationship that is consistent with but by no means exclusively explained by Hypotheses $1 \mathrm{a}$ and $1 \mathrm{~b}$. It could be that the relationship between beliefs and inequality goes in the other direction; perhaps popular beliefs about inequality allow for the (unregulated) growth of income inequality. ${ }^{6}$ The next section addresses this explanation by examining the link between income inequality and concern about inequality.

Alternatively, it may be that the over-time relationship is not as direct as implicitly assumed in the statistical models thus far. Rather, there may be a time lag before the social consequences of growing inequality begin to impact people's beliefs. Whereas my data give much insight into between-country differences, the number of repeated observations is limited, as are changes in income inequality between the survey waves. I can however explore the long-

\footnotetext{
${ }^{6} \mathrm{I}$ thank the anonymous reviewers for making this point.
} 
term within-country changes in inequality for the subset of nine countries included in both the 1987-88 survey and the 2009-12 wave: Austria, Australia, Germany, Hungary, Italy, Switzerland, Poland, the United Kingdom and the United States.

Looking at the relationship between changes in income inequality over this period and citizens' beliefs about meritocracy and structural inequality, I find no relationship between growing inequality and citizens' belief in structural inequality, but I do find a positive and statistically significant relationship $(0.64 ; \mathrm{p}<.05)$ for belief in meritocracy, with consistent estimators for between-country and within-country effects: citizens in countries that have grown more unequal over the past 25 years, all else equal, have come to hold a more meritocratic understanding of inequality (full results are provided in Table A3 in the Appendix). Comparing countries which experienced the largest drop in income inequality to those which experienced the largest growth in inequality, I find a difference of about 7 points in citizens' belief in meritocracy.

A final way to analyze the impact of changes in income-inequality over the long-run, is to leverage the fact that individuals surveyed in the 1980s, 1990s and 2000s may have experienced a change in inequality in their lifetime. By comparing the level of income inequality in their country at the time they were interviewed with what it was when they reached adulthood, we have another means to study the potential impact of growing inequality. To do so, I group people in 5-year cohorts defined by the time they reached adulthood (i.e. $18+$ survey year - age), and for each cohort I document the corresponding Gini level of income inequality and country GDP per capita, as I did for each survey year. The range of cohorts is between those reaching adulthood in the 1950s to those who turned 18 in the 2010s. I then run the same regression models as before, replacing the measures of between-country differences and within-country changes in income inequality by a measure of the difference in income inequality between the year a person reached adulthood, and the year they were surveyed (i.e. inequality now inequality at age 18), adding a control variable indicating the level of income inequality at the year a person reached adulthood, and specifying a fourth level under which individuals are nested (country-cohorts). (Table A4 in the Appendix gives the distribution of respondents by cohort, Figure A2 is a histogram of the changes in income inequality persons have experienced in their lifetime, Figure A3 is a scatter plot of the bivariate relationship between country-level inequality and a person's inequality beliefs, by cohort, and Table A5 provides regression results.) 
Figure 5. Predictive margins of citizens' inequality beliefs by change in income inequality experienced between age 18 and present-day.

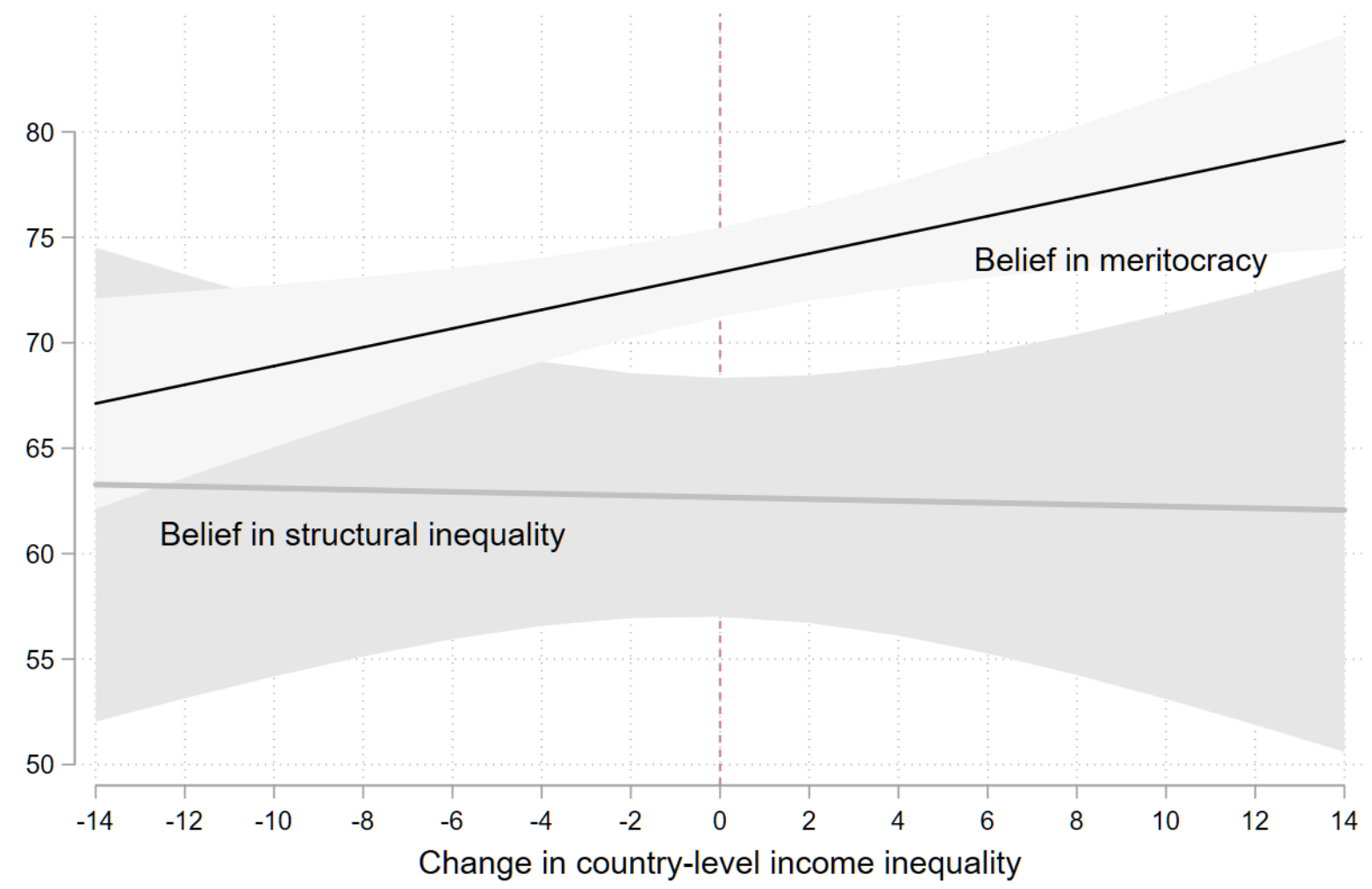

Note: Displayed are citizens' belief in meritocracy (black line) and structural inequality (grey line), on the vertical axis, predicted by the change in country-level income inequality between the year a respondent turned 18 and the year they were surveyed (horizontal axis). A positive number indicates growing inequality, a negative number indicates decreasing inequality, in units of the Gini coefficient of income inequality ranging from 0 (equality) to 100 (maximum inequality). Predictive margins are based on regression estimates reported in Table A5 in the Appendix. Source: Author's calculations from ISSP (2014).

Figure 5 shows the relationship between citizens' belief in meritocracy and the change in income inequality in their country, between the time they were 18 and the time they were interviewed. A positive number indicates growing inequality; a negative number indicates decreasing inequality. I find a small but non-significant relationship between changes in countrylevel income inequality and citizens' belief in structural inequality $(-0.04 ; \mathrm{p}>.10)$ and a strong and statistically significant association with regard to citizens' belief in meritocracy $(0.45 ; \mathrm{p}<$ 
.05). Belief in meritocracy is an estimated 6 points higher for those who have witnesses the largest growth in income inequality, compared to those for whom the level of inequality in their society has remained stable, and 12 points higher compared to those who have experienced the sharpest decrease in inequality.

Taken together, I find support for Hypothesis 1a based on the analysis of betweencountry differences in income inequality and by tracing long-term changes in income inequality within societies, but not for changes between survey waves. The evidence in support of hypothesis $1 \mathrm{~b}$ is much weaker and based only on cross-sectional differences in inequality beliefs. In the next section I consider how differences in inequality beliefs impact citizens' concerns about inequality.

\subsection{Explaining concerns about inequality}

Having established an association between country-level inequality and beliefs about inequality, this section asks if (popular) beliefs about inequality explain citizens' concerns. Table 3 presents the main results of hierarchical regression models estimating individual citizens' concerns about inequality by country-level income inequality and beliefs about inequality (see Table A6 for full results). Models 2 through 5 assess the theoretical expectation that belief in meritocracy dampens concerns about inequality, while belief in structural inequality heightens people's worries. Model 1 addresses the alternative explanation that concerns about inequality are not driven by beliefs, but are a driver of income inequality in their own right. That is, the (unregulated) growth of income inequality could be as much an economic as a political process, driven by a lack of popular concern about inequality. If so, we would expect to find a strong statistical association between the two.

The null model breaks down the variance in concerns about inequality at the individual, country, and country-period level: approximately 67 percent of variance in citizens' concerns reflects differences between individuals within countries, 17 percent is due to country-level factors and about 16 percent can be attributed to forces that are unique to country-periods. 
Table 3. Hierarchical linear regression predicting citizens' concerns about inequality

\begin{tabular}{|c|c|c|c|c|c|c|c|c|c|c|c|}
\hline Variables & Model 0 & Model 1 & & Model 2 & & Model 3 & & \multicolumn{2}{|l|}{ Model 4} & \multicolumn{2}{|l|}{ Model 5} \\
\hline Individual-level controls & & X & & $\mathrm{X}$ & & $\mathrm{X}$ & & $\mathrm{X}$ & & \multicolumn{2}{|l|}{$\mathrm{X}$} \\
\hline \multicolumn{12}{|l|}{ Country-level inequality } \\
\hline Between-countries & & -0.22 & $(.20)$ & 0.03 & $(.20)$ & -0.10 & $(.16)$ & 0.04 & $(.17)$ & 0.04 & $(.17)$ \\
\hline Within-countries & & -0.28 & $(.25)$ & -0.25 & $(.27)$ & -0.22 & $(.23)$ & -0.20 & $(.23)$ & -0.24 & $(.23)$ \\
\hline \multicolumn{12}{|l|}{ Economic development } \\
\hline Between-countries & & -0.04 & $(.25)$ & -0.09 & $(.25)$ & -0.16 & $(.22)$ & -0.20 & $(.22)$ & -0.20 & $(.21)$ \\
\hline Within-countries & & $-0.34 * *$ & $(.11)$ & $-0.40 * *$ & $(.10)$ & $-0.23 *$ & $(.09)$ & $-0.28 * *$ & $(.09)$ & $-0.28 * *$ & $(.09)$ \\
\hline \multicolumn{12}{|l|}{ Belief in meritocracy } \\
\hline Individual-level & & & & $-0.08 * * *$ & $(.02)$ & & & $-0.07 * *$ & $(.02)$ & $-0.07+$ & $(.04)$ \\
\hline Between-countries & & & & $-0.48 *$ & $(.20)$ & & & $-0.29+$ & $(.18)$ & $-0.46 *$ & $(.18)$ \\
\hline Within-countries & & & & 0.31 & $(.46)$ & & & 0.31 & $(.40)$ & 0.19 & $(.41)$ \\
\hline \multicolumn{12}{|l|}{ Belief in structural inequality } \\
\hline Individual-level & & & & & & $0.04 * * *$ & $(.00)$ & $0.04 * * *$ & $(0.00)$ & $0.03 * * *$ & $(.00)$ \\
\hline Between-countries & & & & & & $0.20 * *$ & $(.07)$ & $0.17^{*}$ & $(0.067)$ & 0.02 & $(.07)$ \\
\hline Within-countries & & & & & & $0.26+$ & $(.14)$ & $0.24+$ & $(0.14)$ & 0.19 & $(.14)$ \\
\hline \multicolumn{12}{|l|}{ Social class } \\
\hline Working class & & ref. & & ref. & & ref. & & ref. & & ref. & \\
\hline Lower middle & & $-4.00 * * *$ & $(.26)$ & $-4.00 * * *$ & $(.26)$ & $-3.87 * * *$ & $(.26)$ & $-3.86 * * *$ & $(.26)$ & $-3.17 * * *$ & $(.43)$ \\
\hline Upper middle & & $-9.56 * * *$ & $(.47)$ & $-9.54 * * *$ & $(.47)$ & $-9.35 * * *$ & $(.47)$ & $-9.33 * * *$ & $(.47)$ & $-6.61 * * *$ & $(.74)$ \\
\hline \multicolumn{12}{|l|}{ Time-period } \\
\hline 1991-1993 & & 2.36 & $(1.78)$ & 2.81 & $(1.95)$ & $3.37 *$ & $(1.58)$ & $3.83^{*}$ & $(1.71)$ & $3.80 *$ & $(1.65)$ \\
\hline $2008-2012$ & & $8.21 * *$ & $(2.94)$ & $7.93 * *$ & $(2.76)$ & $8.63 * * *$ & $(2.47)$ & $8.43 * * *$ & $(2.39)$ & $8.66^{* * *}$ & $(2.31)$ \\
\hline \multicolumn{12}{|l|}{ Social class interactions } \\
\hline $\begin{array}{l}\text { Lower middle class X Belief in } \\
\text { meritocracy (indiv) }\end{array}$ & & & & & & & & & & 0.01 & $(.05)$ \\
\hline $\begin{array}{l}\text { Upper middle class X Belief in } \\
\text { meritocracy (indiv) }\end{array}$ & & & & & & & & & & -0.06 & $(.09)$ \\
\hline $\begin{array}{l}\text { Lower middle class X Beliefs } \\
\text { in meritocracy }(\mathrm{b} / \mathrm{w})\end{array}$ & & & & & & & & & & $0.21 * * *$ & $(.05)$ \\
\hline $\begin{array}{l}\text { Upper middle class X Beliefs } \\
\text { in meritocracy }(\mathrm{b} / \mathrm{w})\end{array}$ & & & & & & & & & & $0.52 * * *$ & $(.08)$ \\
\hline $\begin{array}{l}\text { Lower middle class X Beliefs } \\
\text { in meritocracy }(\mathrm{w} / \mathrm{i})\end{array}$ & & & & & & & & & & 0.19 & $(.16)$ \\
\hline $\begin{array}{l}\text { Upper middle class X Beliefs } \\
\text { in meritocracy }(\mathrm{w} / \mathrm{i})\end{array}$ & & & & & & & & & & 0.38 & $(.29)$ \\
\hline $\begin{array}{l}\text { Lower middle class X Belief in } \\
\text { structural inequality (indiv) }\end{array}$ & & & & & & & & & & $0.12 *$ & $(.49)$ \\
\hline
\end{tabular}


Upper middle class X Belief in structural inequality (indiv)

Lower middle class X Beliefs

in structural inequality $(\mathrm{b} / \mathrm{w})$

Upper middle class X Beliefs

in structural inequality $(\mathrm{b} / \mathrm{w})$

Lower middle class X Beliefs

in structural inequality (w/i)

Upper middle class X Beliefs

in structural inequality (w/i)

Constant$$
77
$$

$\begin{array}{lll} & (1.52) & 92.1 * * * \\ 5.65 * * * & (1.37) & 4.07 * * *\end{array}$

$5.47 * * * \quad(.86) \quad 3.21 * * *$

$22.8 * * * \quad(.07) \quad 21.9 * * *$

Var (country)
Var (country-period)
Var (individual

Note. Included in the models, but not displayed is a squared-terms for individual-level belief in meritocracy. w/i refers to within-country; b/w refers to between-country. $\mathrm{N}=49,383$ individuals in 43 country-periods and 23 countries. $* * *=p<.001 ; * *=p<.01 ; *=\mathrm{p}<.05 ;+=\mathrm{p}<.10$ (two-sided). Source: Author's sample of International Social Survey Programme 1987-2009. 
Model 1 shows the relationship between country-level income inequality and individual citizens' concerns about inequality, net of controls. The estimates indicate a non-significant association between citizens' concerns about inequality and within-country inequality as well as between-country income inequality: citizens' concerns about inequality do not follow (growing) inequality in their society. This finding confirms the bivariate null relationship reported in section 4.1 (once outliers are removed) and provides no support to the alternative explanation that country-level inequality is driven by low popular concern about inequality.

Model 2 adds citizens' meritocratic beliefs and indicators of meritocracy beliefs at the country level as well as within-country changes in beliefs. I find that belief in meritocracy is negatively associated with concerns about inequality beliefs, as hypothesized (H2a). The relationship is driven both by individuals' beliefs $(-0.08 ; \mathrm{p}<.01)$ and by popular belief in meritocracy $(-0.48 ; \mathrm{p}<.05)$ as measured by the between-country difference in beliefs. The former relationship is curvilinear, meaning the estimated negative effect of meritocratic beliefs is less strong at higher levels. I do not find a statistically significant relationship between citizens' concerns about inequality and over-time changes in popular belief in meritocracy. Including measures of meritocracy beliefs at the individual and country level leads to a reduction of about 4 percent in individual-level variance, 39 percent in variance at the country-period level, and a reduction of 45 percent in variance at the country level.

In Model 3, I turn to consider the impact of citizens' structuralist beliefs about inequality. In line with my theoretical expectation (H2b), I find a positive association between citizens' concerns about inequality and their belief in the structural nature of inequality, both at the individual-level $(0.04 ; \mathrm{p}<.001)$ and when considering country-level beliefs $(0.20 ; \mathrm{p}<.01)$ and over-time change in beliefs $(0.26 ; \mathrm{p}<0.10)$. The model leads to a reduction in variance of about 4 percent at the individual level, 48 percent at the country-period level and 45 percent at the country level.

Model 4 includes measures of both inequality beliefs to consider the relationship of each belief on citizens' concerns, controlling for the other. I obtain results that are very similar to the findings described above: citizens' belief in meritocracy, at the individual-level and countrylevel, is negatively associated with concerns about inequality, whereas structuralist beliefs are positively associated with concerns about inequality.

In Model 5, I consider whether the relationship between citizens' inequality beliefs and 
their concerns about inequality differs by social class (cf. Roex et al., 2018). I find significant interaction effects for country-average beliefs in structural inequality and meritocracy $(\mathrm{p}<.001)$. Country-level beliefs in structural inequality are a stronger predictor of middle class citizens' concerns about inequality, as compared to working class citizens. Conversely, country-level belief in meritocracy is an especially strong predictor of working class citizens' concerns about inequality. I also find a significant interaction effect between citizens' social class and their belief in structural inequality $(\mathrm{p}<.05)$, but no significant effect when considering over-time change in country-level beliefs. The full model reduces the variance components at the individual level by about 4 percent, at the country-period level by 49 percent, and by 54 percent at the country-level.

I calculate predictive margins from Model 5 to visualize the relationship between beliefs and concerns about inequality by social class in Figure 6. Citizens' concerns about inequality are generally much higher in countries where people believe that inequality reflects structural factors more than meritocratic factors, all else equal. The maximum difference in concerns ranges between 10 and 20 points, for lower and upper middle class citizens. Working class citizens' concerns however are unaffected by societal beliefs. Conversely, citizens are generally less concerned in countries where popular beliefs attribute inequality to hard work rather than structural forces. The difference in concerns is especially large for working class citizens (10 points), smaller for lower middle class citizens (about 5 points), and not significant for people in the upper middle class.

To compare how different inequality beliefs, at the individual and country-level, contribute to citizens' overall concerns about inequality, I standardize effects by the withinindividual standard deviation. Variation in beliefs about meritocracy, at the individual (0.13) and country-level (0.27), account for a total of 0.4 standard-deviations difference in citizens' concerns about inequality across countries and periods. Turning to belief in structural inequality, I find that citizens' varying perspectives account for as much as 0.7 standard-deviations difference in concerns about inequality. About half of this association (0.36) is driven by between-country differences in popular belief, and about a quarter each reflects individual beliefs (0.18) and over-time changes in popular beliefs (0.17). 
Figure 6. Predictive margins of citizens' concerns about inequality by social class and popular inequality beliefs
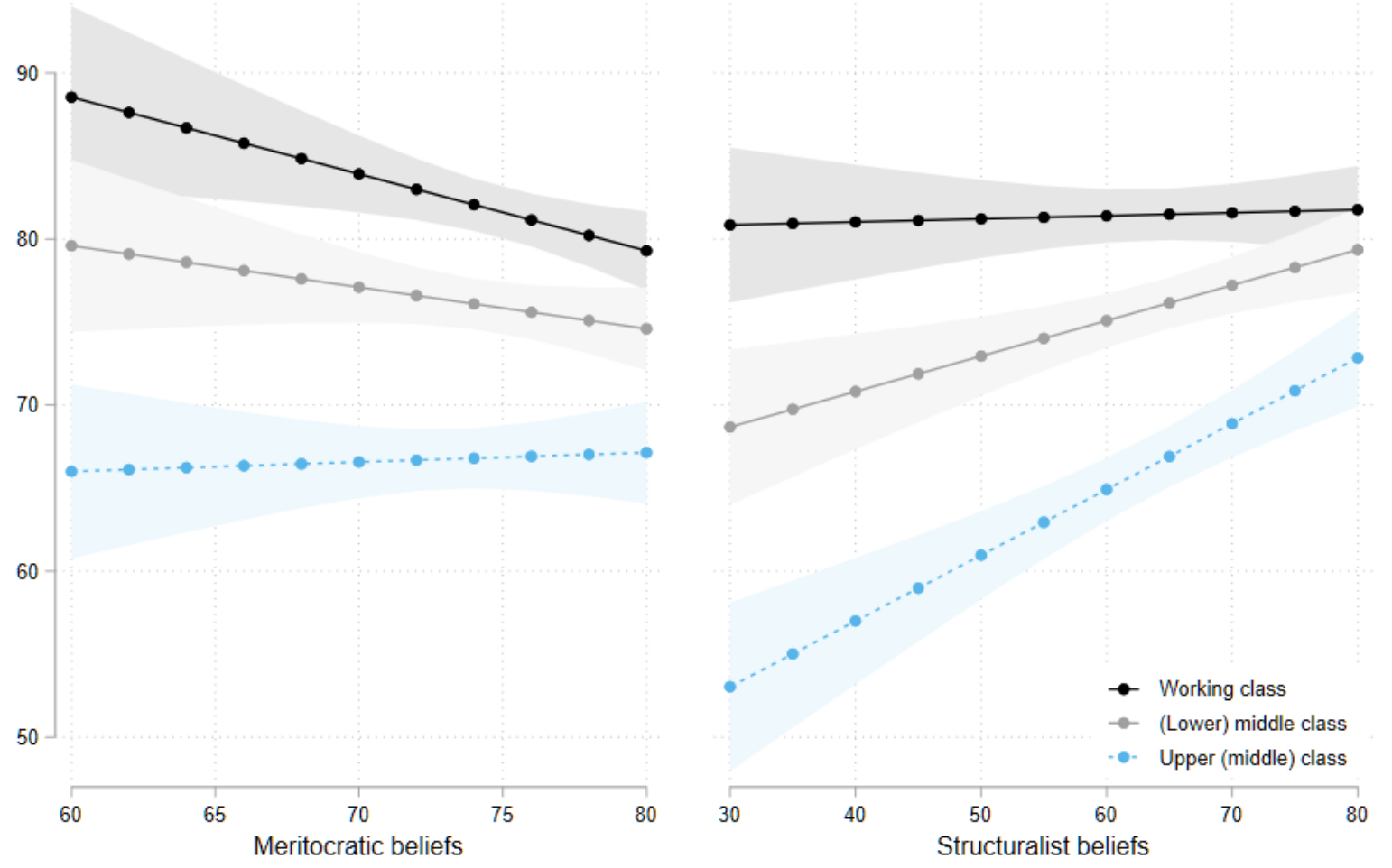

Note: Displayed on the vertical axis are citizens' concerns about inequality by social class, predicted by popular (country-level) beliefs in meritocracy (left) and structural inequality (right), on the horizontal axis. Predictive margins are based on regression estimates reported in Table 3 , Model 5. Source: Author's calculations from ISSP (2014).

In sum, I have shown that citizens' concerns about inequality are strongly associated with their beliefs about the forces underlying income inequality. What fuels citizens' concerns about inequality is their belief that income inequality reflects structural processes that benefit some people, while putting others at a disadvantage. Conversely, belief in meritocracy dampens citizens' concerns. My findings suggest that concerns are driven both by people's own beliefs about inequality and by popular beliefs in a given country and time-period. Evidence for the latter comes mainly from between-country comparisons; I find only partial evidence when considering within-country changes in popular inequality beliefs. 


\section{Conclusions}

Scholars and politicians have been puzzled by the lack of popular concern about the rising level of income inequality across the West. In this article I provide an explanation by theorizing, and empirically describing, a relationship between actual inequality and beliefs about inequality. I argue that what explains citizens' consent to inequality is their conviction that poverty and wealth are the outcomes of a fair meritocratic process. Citizens' meritocracy beliefs are solidified by the fact that people are unable to see the full extent of inequality in their society, nor develop an awareness of the structural processes shaping unequal life outcomes. The reason for people's inability to see what separates them from their fellow citizens, is that the lives of the rich and poor are increasingly divided between separate institutions: people live in neighborhoods, go to schools, and pick romantic partners and friends that fit their education and income level (Logan, 2011; Massey and Tannen, 2016; Musterd, 2005; Reardon and Bischoff, 2011; Reardon and Owens, 2014; Tammaru et al., 2016). Housing segregation, school stratification and social homogamy mean that one's chances of getting to know someone from a different socioeconomic background, let alone developing an understanding of another person's privilege or plight, are slim. These then are the processes that produce the paradox we face, where citizens of some of the world's most unequal societies think of their country as the paragon of meritocracy (Bucca, 2016; McCall, 2013; Whyte, 2011).

In this article, I show that citizens across the West have become more convinced that theirs is a meritocratic society. While countries have grown more unequal since the 1980s, nowhere have citizens lost faith in meritocracy. In fact, the empirical record suggests that belief in meritocracy in the Western world has never been as strong as it is today. Analyzing variation between countries, I find that citizens in unequal societies more strongly believe that meritocratic factors are at the root of societal success, while giving less thought to structural, nonmeritocratic, forces. Closely examining the variable pattern of growing inequality across the West does not give me much purchase on citizens' changing beliefs about inequality, but examining the long trend in levels of income inequality over the 1987-2012 period, I find that growing inequality goes together with a strengthening of citizens' meritocratic beliefs (cf. Schröder, 2017). I obtain similar results from a cohort analysis, tracing citizens' beliefs and the trend in inequality they have experienced in their lifetime. Citizens' beliefs about inequality, in turn, explain whether or not they express concern about inequality in their society. 
The research presented in this paper however is not without its limitations. In the empirical analysis I have estimated the association between country-level inequality and beliefs about inequality by breaking down the within-country and between-country variation. If societallevel inequality drives people's beliefs about inequality, then we would expect to see this reflected both in differences in citizens' beliefs by (stable) patterns of between-country income inequality and in (dynamic) changes in inequality over-time. I find consistent statistical evidence for the former. I find no evidence however for the theorized effect of within-country changes in income inequality between surveys. This shortcoming is a likely reflection of the relatively small set of countries that can be compared across time, as well as the limited changes in income inequality within this set of countries. Alternatively, it may be that societal inequality impacts citizens' beliefs through a longer process than can be captured by between-survey wave changes, which is consistent with my analysis of changes in income inequality between 1987 and 2012 as well as the cohort analysis comparing the level of inequality in the year a person was interviewed to that of the year they reached adulthood. Based on the available evidence I cannot adjudicate between these and other explanations (see below for a discussion).

A further limitation lies in the fact I have taken income inequality as a proxy for its theorized social and spatial consequences. That is, I have assumed, rather than empirically assessed, that country-level income inequality shapes citizens' interactions across socioeconomic lines and conditions their exposure to inequality. This assumption is supported by evidence from the US that "income inequality is a strong and consistent predictor of income segregation," and the (Reardon et al., 2018) and that rising income inequality goes together with increasing residential sorting (Reardon and Bischoff, 2011; Watson, 2009). In practice, citizens' social networks and neighborhoods may span across fault lines, even in the most unequal societies. Similarly, living in a relatively egalitarian society is no guarantee for socioeconomically diverse contexts and interactions. In other words, measuring inequality at the country level is a relatively crude way to capture people's day-to-day experiences with inequality. The problem of measuring these experiences is twofold. Socioeconomic segregation is a social phenomenon typically studied at the neighborhood or regional level, where it impacts families and communities, but rarely as something characterizing either individuals or whole societies. There have been efforts to collect country-level data on (ethnic) segregation across societies (e.g. Haller et al., 2016; Musterd, 2005), but scholars are quick to note the difficulties in making comparisons between 
countries and over time. Adding to the paucity of available data is a conceptual problem: it is not at all clear what segregation means as a country-level phenomenon, other than a proxy for the typical person's social environment. In the absence of detailed, comparative, and longitudinal data on social networks and neighborhoods, scholars must rely on indirect indicators for people's experiences.

Without direct measurement of the theorized process linking income inequality to citizens' beliefs and concerns about inequality, I cannot rule out alternative explanations. Sachweh (2012), for instance, argues that (German) citizens' attitudes toward inequality are best understood as part of a 'moral economy' of shared repertoires that is supportive of, rather than caused by, the level of inequality in society. Other studies similarly suggest that the causal arrow may go the other way: popular consent to inequality may be the cause of (growing) income inequality rather than its consequence (Janmaat, 2013; Schröder, 2017). Such could be the case, for instance, if pro-market governments jointly promote income inequality and meritocratic discourse. ${ }^{7}$ Empirically however, the link between popular opinion and government economic policy is far from straightforward (Milanovic, 2000; Iversen and Goplerud, 2018; Kenworthy and McCall, 2008; Schmidt-Catran, 2016; Gilens and Page, 2014). In this paper, I find no evidence either of a statistical relationship between country-level inequality and citizen's concerns about inequality, as would be the expectation if inequality was the result of popular consent.

These limitations suggest paths for future work, for theory, and for the politics of inequality. With regard to theorizing about income inequality, my findings suggest that we may want to pay more attention to the role of experiences in reinforcing inequality (cf. Merolla et al., 2011; Edmiston, 2018; Massey and Tannen, 2016; Dawtry et al., 2015). Looking at politics and policy preferences through an experiential lens helps understand when and why rising inequality does not lead to popular concern. The analysis presented in this paper suggests that country-level inequality conditions people's experiences, but future research needs to explore different contexts that matter. A particularly interesting question is how national-level inequality translates into or interacts with inequality at the neighborhood level and in social networks.

A necessary starting point for understanding the politics of inequality, is to disentangle the relationship between experiences, beliefs and preferences. Publics in unequal societies may

\footnotetext{
${ }^{7}$ I thank the anonymous reviewer for suggesting this alternative mechanism.
} 
find themselves stuck in a feedback loop, where more inequality paradoxically leads them to experience less of it—and care less about it (Kelly and Enns, 2010; Whyte, 2011; Minkoff and Lyons, 2018). Breaking that loop requires taking seriously people's beliefs and lived experiences, and designing social policy to bring the two in closer alignment. Until then, there is nothing surprising about the fact that people in highly unequal societies approach politics from the highly skewed vantage point of their own experiences.

\section{References}

Alesina, A. and Glaeser, E. (2004) Fighting Poverty in the US and Europe: A World of Difference, London, Oxford University Press.

Alesina, A., Stantcheva, S. and Teso, E. (2018) 'Intergenerational Mobility and Preferences for Redistribution', American Economic Review, 108, 521-554.

Atkinson, A. B., Piketty, T. and Saez, E. (2011) 'Top Incomes in the Long Run of History', Journal of Economic Literature, 49, 3-71.

Bénabou, R. and Tirole, J. (2006) 'Belief in a Just World and Redistributive Politics', The Quarterly Journal of Economics, 121, 699-746.

Bozick, R., Alexander, K., Entwisle, D., Dauber, S. and Kerr, K. (2010) 'Framing the Future: Revisiting the Place of Educational Expectations in Status Attainment', Social Forces, 88, 2027-2052.

Breen, R. and Jonsson, J. O. (2005) 'Inequality of Opportunity in Comparative Perspective: Recent Research on Educational Attainment and Social Mobility', Annual Review of Sociology, 31, 223-243.

Brooks, C. and Manza, J. (2013) 'A Broken Public? Americans' Responses to the Great Recession', American Sociological Review, 78, 727-748.

Bryan, M. L. and Jenkins, S. P. (2016) 'Multilevel Modelling of Country Effects: A Cautionary Tale', European Sociological Review, 32, 3-22.

Bucca, M. (2016) 'Merit and Blame in Unequal Societies: Explaining Latin Americans' Beliefs about Wealth and Poverty', Research in Social Stratification and Mobility, 44, 98-112.

Corak, M. (2004) Generational Income Mobility in North America and Europe, Cambridge, Cambridge University Press.

Cruces, G., Perez-Truglia, R. and Tetaz, M. (2013) 'Biased Perceptions of Income Distribution and Preferences for Redistribution: Evidence from a Survey Experiment', Journal of Public Economics, 98, 100-112.

Dallinger, U. (2010) 'Public Support for Redistribution: What Explains Cross-National Differences?', Journal of European Social Policy, 20, 333-349.

Dawtry, R. J., Sutton, R. M. and Sibley, C. G. (2015) 'Why Wealthier People Think People Are Wealthier, and Why It Matters: From Social Sampling to Attitudes to Redistribution', Psychological Science, 26, 1389-1400.

Duru-Bellat, M. and Tenret, E. (2012) 'Who's for Meritocracy? Individual and Contextual Variations in the Faith', Comparative Education Review, 56, 223-247. 
Edmiston, D. (2018) 'The Poor "Sociological Imagination” of the Rich: Explaining Attitudinal Divergence towards Welfare, Inequality, and Redistribution', Social Policy \& Administration, 53, 1-15.

Fairbrother, M. (2014) 'Two Multilevel Modeling Techniques for Analyzing Comparative Longitudinal Survey Datasets', Political Science Research and Methods, 2, 119-140.

Gijsberts, M. (2002) 'The Legitimation of Income Inequality in State-Socialist and Market Societies', Acta Sociologica, 45, 269-285.

Gilens, M. and Page, B. I. (2014) 'Testing Theories of American Politics: Elites, Interest Groups, and Average Citizens', Perspectives on Politics, 12, 564-581.

Gimpelson, V. and Treisman, D. (2018) 'Misperceiving Inequality', Economics \& Politics, 30, 27-54.

Gugushvili, A. (2016) 'Intergenerational Social Mobility and Popular Explanations of Poverty: A Comparative Perspective', Social Justice Research, 29, 402-428.

Hall, P. and Lamont, M. (2013) Social Resilience In The Neoliberal Era, Cambridge, Cambridge University Press.

Haller, M., Eder, A. and Stolz, E. (2016) 'Ethnic Stratification and Patterns of Income Inequality Around the World: A Cross-National Comparison of 123 Countries, Based on a New Index of Historic Ethnic Exploitation', Social Indicators Research, 128, 1047-1084.

Halleröd, B. (2011) 'What Do Children Know About Their Futures: Do Children's Expectations Predict Outcomes in Middle Age?', Social Forces, 90, 65-83.

Hills, J. (2002) 'Following or Leading Public Opinion? Social Security Policy and Public Attitudes Since 1997', Fiscal Studies, 23, 539-558.

Hochschild, J. L. (1996) Facing Up to the American Dream: Race, Class, and the Soul of the Nation, Princeton, NJ, Princeton University Press.

Hunt, M. O. (2002) 'Religion, Race/Ethnicity, and Beliefs about Poverty', Social Science Quarterly, 83, 810-831.

Irwin, S. (2018) 'Lay Perceptions of Inequality and Social Structure', Sociology, 52, 211-227.

ISSP Research Group (2014) International Social Survey Programme: Social Inequality I-IV ISSP 1987-1992-1999-2009, Cologne, GESIS Data Archive.

Iversen, T. and Goplerud, M. (2018) 'Redistribution Without a Median Voter: Models of Multidimensional Politics', Annual Review of Political Science, 21, 295-317.

Jæger, M. M. (2013) 'The Effect of Macroeconomic and Social Conditions on the Demand for Redistribution: A Pseudo Panel Approach', Journal of European Social Policy, 23, 149163.

Janmaat, J. G. (2013) 'Subjective Inequality: A Review of International Comparative Studies on People's Views about Inequality', European Journal of Sociology, 54, 357-89.

Jost, J. T., Banaji, M. R. and Nosek, B. A. (2004) 'A Decade of System Justification Theory: Accumulated Evidence of Conscious and Unconscious Bolstering of the Status Quo', Political Psychology, 25, 881-919.

Kalleberg, A. L. (2009) 'Precarious Work, Insecure Workers: Employment Relations in Transition', American Sociological Review, 74, 1-22.

Kelly, N. J. and Enns, P. K. (2010) 'Inequality and the Dynamics of Public Opinion: The SelfReinforcing Link Between Economic Inequality and Mass Preferences’, American Journal of Political Science, 54, 855-870.

Kenworthy, L. and McCall, L. (2008) 'Inequality, Public Opinion and Redistribution', SocioEconomic Review, 6, 35-68. 
Kluegel, J. R. and Smith, E. R. (1986) Beliefs About Inequality: Americans' Views of What Is and What Ought to Be, New York, Transaction Publishers.

Kuklinski, J. H., Quirk, P. J., Jerit, J., Schwieder, D. and Rich, R. F. (2000) 'Misinformation and the Currency of Democratic Citizenship', The Journal of Politics, 62, 790-816.

Kuziemko, I., Norton, M. I., Saez, E. and Stantcheva, S. (2015) 'How Elastic Are Preferences for Redistribution? Evidence from Randomized Survey Experiments', American Economic Review, 105, 1478-1508.

Lamont, M. (1992) Money, Morals, and Manners: The Culture of the French and the American Upper-Middle Class, Chicago, IL, University of Chicago Press.

Lamont, M., Beljean, S. and Clair, M. (2014) 'What Is Missing? Cultural Processes and Causal Pathways to Inequality', Socio-Economic Review, 12, 573-608.

Larsen, C. A. (2016) 'How Three Narratives of Modernity Justify Economic Inequality', Acta Sociologica, 59, 93-111.

Lerner, M. J. (1980) The Belief in a Just World. A Fundamental Delusion, New York, Plenum Press.

Lockwood, D. (1966) 'Sources of Variation in Working Class Images of Society', The Sociological Review, 14, 249-267.

Logan, J. R. (2011) Separate and Unequal: The Neighborhood Gap for Blacks, Hispanics and Asians in Metropolitan America. Project US2010 Report., New York, NY and Providence, RI, Russell Sage Foundation and Brown University.

Lübker, M. (2007) 'Inequality and the Demand for Redistribution: Are the Assumptions of the New Growth Theory Valid?', Socio-Economic Review, 5, 117-148.

MacLeod, L., Montero, D. and Speer, A. (1999) 'America's Changing Attitudes toward Welfare and Welfare Recipients, 1938-1995', Journal of Sociology and Social Welfare, 26, 175.

Massey, D. S. and Tannen, J. (2016) 'Segregation, Race, and the Social Worlds of Rich and Poor'. In Kirsch, I. and Braun, H. (eds) The Dynamics of Opportunity in America. Evidence and Perspectives, Dordrecht, Springer, pp. 13-34.

McCall, L. (2013) The Undeserving Rich. American Beliefs about Inequality, Opportunity, and Redistribution, New York, Cambridge University Press.

McCall, L. and Percheski, C. (2010) 'Income Inequality: New Trends and Research Directions', Annual Review of Sociology, 36, 329-347.

McCarty, N. and Pontusson, J. (2011) 'The Political Economy of Inequality and Redistribution'. In Salverda, W., Nolan, B., and Smeeding, T. M. (eds) The Oxford Handbook of Economic Inequality, Oxford, Oxford University Press, pp. 665-92.

McCoy, S. K. and Major, B. (2007) 'Priming Meritocracy and the Psychological Justification of Inequality', Journal of Experimental Social Psychology, 43, 341-351.

Merolla, D. M., Hunt, M. O. and Serpe, R. T. (2011) 'Concentrated Disadvantage and Beliefs about the Causes of Poverty: A Multi-Level Analysis.', Sociological Perspectives, 205228.

Mijs, J. J. B. (2016) 'The Unfulfillable Promise of Meritocracy: Three Lessons and Their Implications for Justice in Education', Social Justice Research, 29, 14-34.

Mijs, J. J. B. (2018a) 'Visualizing Belief in Meritocracy, 1930-2010', Socius, 4.

Mijs, J. J. B. (2018b) 'Inequality Is a Problem of Inference: How People Solve the Social Puzzle of Unequal Outcomes', Societies, 8, 64.

Mijs, J. J. B., Bakhtiari, E. and Lamont, M. (2016) 'Neoliberalism and Symbolic Boundaries in Europe Global Diffusion, Local Context, Regional Variation', Socius, 2, 1-8. 
Milanovic, B. (2000) 'The Median-Voter Hypothesis, Income Inequality, and Income Redistribution: An Empirical Test with the Required Data', European Journal of Political Economy, 16, 367-410.

Milanovic, B. (2013) All the Ginis Dataset, Washington, D.C., World Bank Group. Mills, C. W. (1959) The Sociological Imagination, London, Oxford University Press.

Minkoff, S. L. and Lyons, J. (2018) 'Living With Inequality: Neighborhood Income Diversity and Perceptions of the Income Gap', American Politics Research, forthcoming.

Morris, M. and Western, B. (1999) 'Inequality in Earnings at the Close of the Twentieth Century', Annual Review of Sociology, 25, 623-657.

Musterd, S. (2005) 'Social and Ethnic Segregation in Europe: Levels, Causes, and Effects', Journal of Urban Affairs, 27, 331-348.

Nair, G. (2018) 'Misperceptions of Relative Affluence and Support for International Redistribution', The Journal of Politics, 80, 815-830.

Neckerman, K. M. and Torche, F. (2007) 'Inequality: Causes and Consequences', Annual Review of Sociology, 33, 335-357.

Newman, B. J. (2014) 'My Poor Friend: Financial Distress in One's Social Network, the Perceived Power of the Rich, and Support for Redistribution', The Journal of Politics, 76, 126-138.

Newman, B. J., Johnston, C. D. and Lown, P. L. (2015) 'False Consciousness or Class Awareness? Local Income Inequality, Personal Economic Position, and Belief in American Meritocracy', American Journal of Political Science, 59, 326-340.

Newman, K. S. (1999) Falling from Grace: Downward Mobility in the Age of Affluence, Berkeley, CA, University of California Press.

Norton, M. I. and Ariely, D. (2011) 'Building a Better America-One Wealth Quintile at a Time', Perspectives on Psychological Science, 6, 9-12.

OECD (2015) In It Together: Why Less Inequality Benefits All, Paris, Organisation for Economic Co-Operation and Development.

OECD (2017) OECD Compendium of Productivity Indicators 2017, Paris, Organisation for Economic Co-Operation and Development.

Osberg, L. and Smeeding, T. (2006) "“Fair" Inequality? Attitudes toward Pay Differentials: The United States in Comparative Perspective', American Sociological Review, 71, 450-473.

Owens, A. (2016) 'Inequality in Children's Contexts Income Segregation of Households with and without Children', American Sociological Review, 81, 549-574.

Paskov, M. and Dewilde, C. (2012) 'Income Inequality and Solidarity in Europe', Research in Social Stratification and Mobility, 30, 415-432.

Piketty, T. and Saez, E. (2003) 'Income Inequality in the United States, 1913-1998', The Quarterly Journal of Economics, 118, 1-41.

Reardon, S. F. and Bischoff, K. (2011) 'Income Inequality and Income Segregation', American Journal of Sociology, 116, 1092-1153.

Reardon, S. F., Bischoff, K., Owens, A. and Townsend, J. B. (2018) 'Has Income Segregation Really Increased? Bias and Bias Correction in Sample-Based Segregation Estimates', Demography, forthcoming.

Reardon, S. F. and Owens, A. (2014) '60 Years After Brown: Trends and Consequences of School Segregation', Annual Review of Sociology, 40, 199-218.

Reynolds, J. and Xian, H. (2014) 'Perceptions of Meritocracy in the Land of Opportunity', Research in Social Stratification and Mobility, 36, 121-137. 
Roex, K. L., Huijts, T. and Sieben, I. (2018) 'Attitudes towards Income Inequality: "Winners" versus "Losers" of the Perceived Meritocracy', Acta Sociologica, forthcoming.

Roth, C. and Wohlfart, J. (2017) Experienced Inequality and Preferences for Redistribution, SSRN Scholarly Paper, Rochester, NY, Social Science Research Network.

Runciman, W. G. (1966) Relative Deprivation and Social Justice: A Study of Attitudes to Social Inequality in Twentieth-Century England, Berkeley, CA, University of California Press.

Sachweh, P. (2012) 'The Moral Economy of Inequality: Popular Views on Income Differentiation, Poverty and Wealth', Socio-Economic Review, 10, 419-445.

Schmidt-Catran, A. W. (2016) 'Economic Inequality and Public Demand for Redistribution: Combining Cross-Sectional and Longitudinal Evidence', Socio-Economic Review, 14, 119-140.

Schmidt-Catran, A. W. and Fairbrother, M. (2016) 'The Random Effects in Multilevel Models: Getting Them Wrong and Getting Them Right', European Sociological Review, 32, 2338.

Schröder, M. (2017) 'Is Income Inequality Related to Tolerance for Inequality?', Social Justice Research, 30, 23-47.

Shedd, C. (2015) Unequal City. Race, Schools, and Perceptions of Injustice, New York, Russell Sage Foundation.

Smeeding, T. M. (2005) 'Public Policy, Economic Inequality, and Poverty: The United States in Comparative Perspective', Social Science Quarterly, 86, 955-983.

Snijders, T. A. B. and Bosker, R. J. (2012) Multilevel Analysis: An Introduction to Basic and Advanced Multilevel Modeling, Thousand Oaks, CA, Sage.

Somers, M. R. and Block, F. (2005) 'From Poverty to Perversity: Ideas, Markets, and Institutions over 200 Years of Welfare Debate', American Sociological Review, 70, 260-287.

Svallfors, S. (2011) 'A Bedrock of Support? Trends in Welfare State Attitudes in Sweden, 19812010', Social Policy \& Administration, 45, 806-825.

Tammaru, T., Marczinczak, S., van Ham, M. and Musterd, S. (eds) (2016) Socio-Economic Segregation in European Capital Cities, New York, Routledge.

Tropp, L. R. and Pettigrew, T. F. (2005) 'Relationships between Intergroup Contact and Prejudice among Minority and Majority Status Groups', Psychological Science, 16, 951957.

Trump, K.-S. (2017) 'Income Inequality Influences Perceptions of Legitimate Income Differences', British Journal of Political Science, 48, 929-952.

VanHeuvelen, T. (2017) 'Unequal Views of Inequality: Cross-National Support for Redistribution 1985-2011', Social Science Research, 64, 43-66.

Watson, T. (2009) 'Inequality and the Measurement of Residential Segregation by Income in American Neighborhoods', Review of Income and Wealth, 55, 820-844.

Weaver, R. K., Shapiro, R. Y. and Jacobs, L. R. (1995) 'Polls Trends: Welfare', Public Opinion Quarterly, 59, 606-627.

Whyte, M. (2011) 'Myth of the Social Volcano: Popular Responses to Rising Inequality in China'. In The People's Republic of China at 60., Cambridge, MA, Harvard University Asia Center.

Wietzke, F.-B. (2016) 'Kicking Away the Ladder? Poverty Reduction and Public Support for Redistribution in Emerging Economies', Socio-Economic Review, 14, 419-442.

Wu, A. M. and Chou, K.-L. (2017) 'Public Attitudes towards Income Redistribution: Evidence from Hong Kong', Social Policy \& Administration, 51, 738-754. 